\title{
SPALONA ZIEMIA. \\ LOSY BUŁGARSKIEGO ZAPLECZA GOSPODARCZEGO W CZASIE WYPRAWY NIKEFORA I GENIKA Z ROKU 811
}

\author{
KIRIE MARINOW
}

\begin{abstract}
A scorched earth: The fate of the Bulgarian economic background during the expedition of Nikephoros I Genikos of 811 .

The article is dedicated to the impact of the military expedition led by the Byzantine emperor Nikephoros I Genikos (802-811) on the overall political and economic situation of the Bulgarian state. During the military operations carried out in the Khanate, the Byzantine forces undertook the devastation of arable fields, the killing of farm animals and probably committed murders of the local population. Many researchers associate this activity with the loosening of discipline within the army, which was to be the result of a lack of control on the part of the commander-in-chief. On the basis of the correlation and rationalization of the sources in the matter, we have to interpret all these actions in a completely different way, as a conscious activity aimed at causing the Bulgarians the greatest possible losses by the imperial army. Moreover, the interpretation contradicts the universally accepted thesis, that the imperial campaign was aimed at eliminating Bulgarian statehood and incorporating its lands into Byzantium. It seems, therefore, that the purpose of the described activities was to exclude, for a long time, Khan Kroum (796/803-814) and his subordinates from military engagement in Thrace, Macedonia, i.e. areas where the Empire tried to regain and consolidate its influence.
\end{abstract}

Streszczenie. Celem artykułu jest przedstawienie wpływu wielkiej wyprawy zbrojnej pod wodzą cesarza bizantyńskiego Nikefora I Genika (802-811) na ogólną polityczno-gospodarczą sytuację ziem państwa bułgarskiego. W trakcie działań zbrojnych na terenie chanatu, wojska bizantyńskie niszczyły pola uprawne, wybijały zwierzęta hodowlane i prawdopodobnie dopuściły się mordów na miejscowej ludności,. Zazwyczaj badacze tłumaczą te działania rozluźnieniem dyscypliny w armii cesarskiej, w związku z brakiem decyzyjności ze strony głównodowodzącego. Na podstawie korelacji i racjonalizacji źródeł dotyczących kampanii należy uznać, że niszczycielska aktywność wojskowa była podejmowana świadomie, z myślą o zadaniu Bułgarom możliwie największych strat gospodarczych. Co więcej, taka interpretacja przeczy powszechnej tezie, że wspomniana kampania cesarska miała na celu likwidację państwowości bułgarskiej i inkorporację jej ziem do Bizancjum. Należy uznać, że celem opisywanych działań było raczej wyłączenie na dłuższy czas chana Kruma (796/803814) i jego podwładnych z zaangażowania zbrojnego na terenie Tracji i Macedonii, czyli obszarów, na których cesarstwo starało się odzyskać oraz umocnić swoje wpływy.

Autor: Kirił Marinow, Uniwersytet Łódzki, Wydział Filozoficzno-Historyczny, Instytut Historii, Katedra Historii Bizancjum, ul. Aleksandra Kamińskiego 27a, 90-219 Łódź, kiril.marinow@uni.lodz.pl, ORCID ID: https:// orcid.org/0000-0003-0224-3965

Słowa kluczowe: Bizancjum, wczesnośredniowieczna Bułgaria, Nikefor I Genik, chan Krum, góry Hemos, wojskowość bizantyńska, wojny bizantyńsko-bułgarskie, historia wczesnośredniowieczna, Teofanes Wyznawca, Kronika bizantyńska roku 811

Keywords: Byzantium, Early Medieval Bulgaria, Nikephoros I Genikos, Khan Kroum, Haimos Mountains, Byzantine Warfare, Byzantine-Bulgarian Wars, Early Medieval History, Theophanes Confessor, The Byzantine chronicle of 811 
Balcanica Posnaniensia. Acta et studia, XXVII, Poznań 2020, Wydawnictwo Wydziału Historii UAM, pp. 1746, ISBN 978-83-66355-54-5, ISSN 0239-4278. Polish text with summaries in English and Polish.

doi.org/10.14746/bp.2020.27.2

W związku z narastającym konfliktem bizantyńsko-bułgarskim, który związany był z rywalizacją o terytoria geograficznej Macedonii oraz Północnej Tracji - od połowy VIII w., Bizantyńczycy dążyli do ich odzyskania, a po 807 r. doszło do przeorientowania bułgarskiej ekspansji z kierunku północno-zachodniego na południe i południowy zachód od masywu gór Hemos (obejmującego współczesne masywy Przedgórza Staropłanińskiego, właściwej Starej Płaniny oraz Srednej Gory) ${ }^{1}$, który dotychczas stanowił stabilną południową granicę naddunajskiego chanatu - w roku 811 cesarz bizantyński Nikefor I Genik (802-811) poprowadził wielką wyprawę wojenną do samego serca państwa bułgarskiego, a więc na północ od wspomnianego pasma górskiego. Początkowo okazała się ona spektakularnym sukcesem wojska cesarskiego, gdyż po udanym przekroczeniu granicznych przełęczy górskich i wejściu na wewnętrzne terytoria bułgarskie Bizantyńczycy odnieśli kilka zwycięstw i zdołali opanować Pliskę, stołeczny ośrodek chana Kruma (796/803-814), ówczesnego władcy bułgarskiego. Oba podstawowe źródła relacjonujące omawianą kampanię zbrojną, a mianowicie Chronografia Teofanesa Wyznawcy², żyjącego w czasach omawianych zajść, jak

1 Na temat tego masywu górskiego zob. E. Oberhummer, Haimos, w: Paulys Real-Encyclopädie der classischen Altertumswissenschaft, t. 7/2, red. W. Kroll, Stuttgart 1912, s. 2221-2226; H. Inalc1k, Balkan, w: The Encyclopaedia of Islam. New Edition, t. 1, A-B, red. H.A.R. Gibb, J.H. Kramers, E. LéviProvençal, B. Lewis, Ch. Pellat, J. Schacht, Leiden-London 1960, s. 998-1000; T. Lehr-Spławiński, Bałkany, w: Stownik Starożytności Stowiańskich. Encyklopedyczny zarys kultury Słowian od czasów najdawniejszych do schyłku wieku XII, t. 1, A-E, red. W. Kowalenko, G. Labuda, T. Lehr-Spławiński, Wrocław-Warszawa-Kraków 1961, s. 71; L. Moszyński, W. Swoboda, Haemus, w: Stownik Starożytności Słowiańskich, t. 2, Kraków 1964, s. 182; I. Dujčev, W. Rösener, Balkan, w: Lexikon des Mittelalters, Bd. I, München-Zürich 1977, s. 1380-1381; A.P. Kazhdan, Balkans, w: The Oxford Dictionary of Byzantium, t. 1, red. Idem, New York-Oxford 1991, s. 248-249; P. Soustal, Thrakien (Thrakē, Rodopē und Haimimontos), Tabula Imperii Byzantini, Bd. VI, Wien 1991, s. 279-280; К. Гагова, Тракия през българското Средновековие. Историческа география, София 2002, s. 319-322; В. Николов, М. Йорданова, Планините в България, София 2002, s. 9-57; К. Marinow, The Haemus Mountains and the Geopolitics of the First Bulgarian Empire: An Overview, „Зборник радова Византолошког института" 2014, nr 51, s. 17-32.

2 O Teofanesie i jego dziele historycznym zob. m.in. A. Kazhdan, L.F. Sherry, Ch. Angelidi. A History of Byzantine Literature (650-850), Athens 1999, s. 205-235; W. Treadgold, The Middle Byzantine Historians, New York-Basingstoke 2013, s. 38-77; Travaux et Mémoires, nr 19: Studies in Theophanes, red. M. Jankowiak, F. Montinaro, Paris 2015 (zbiór studiów); A. Kompa, Gnesioi filoi: the Search for George Syncellus' and Theophanes the Confessor's Own Words, and the Authorship of Their Oeuvre, „Studia Ceranea” 2015, nr 5, s. 155-230. 
również tzw. Kronika bizantyńska roku 811 (inaczej Fragment Dujczewa) ${ }^{3}$, ostatecznie zredagowana po połowie lat sześćdziesiątych IX w., a jak najczęściej się przyjmuje będąca albo spisanym świadectwem któregoś z uczestników samej wyprawy, albo tekstem autora, który miał dostęp do takiej relacji, zgodnie podkreślają dobre samopoczucie bizantyńskiego władcy i jego przekonanie o odniesieniu pełnego zwycięstwa nad wrogiem. Piszą wręcz o jego wzbiciu się w pychę i dopuszczeniu do rozluźnienia morale wśród żołnierzy bizantyńskich. O zaniedbaniu spraw wojskowych i kompletnym zlekceważeniu przeciwnika ${ }^{4}$. Po spędzeniu bowiem kilku dni w Plisce, podczas wycofywania się na terytoria bizantyńskie, obozujące w górach oddziały cesarskie stały się ofiarą porannego ataku bułgarskiego (26 lipca 811 r.), który skutkował jedną z największych i najsławniejszych klęsk bizantyńskich w dziejach konfliktów cesarstwa z północnym sąsiadem ${ }^{5}$. Bitwy, w której zginął sam cesarz, co nie zdarzyło się

3 O tym źródle zob. m.in. Ив. Дуйчев, Нови житийни данни за похода на имп. Никифора I 8 България през 811 год., „Списание на Българската академия на науките, 54, Клон историко-филологичен и Философско-обществен” 1937, nr 26, s. 147-188; В. Бешевлиев, Новият извор за поражението на Никифора I в България през 811 година, „Годишник на Софийския Университет. Историкофилологически факултет” 1936, nr 33.2, s. 1-8; H. Grégoire, Un nouveau fragment du «Scriptor Incertus de Leone Armenio», „Byzantion” 1936, no. 11, s. 417-427; idem, Du nouveau sur la Chronographie byzantine: "Scriptor incertus de Leone Armenio» est le dernier continuateur de Malalas, „Bulletin de la Classe des Lettres de L'Academie de Belgique" 1936, nr 5, s. 420-436; R. Browning, Notes on the «Scriptor Incertus de Leone Armenio», „Byzantion” 1965, nr 35, s. 389-411; I. Dujčev, La chronique byzantine de l'an 811, „Travaux et Mémoires” 1965, nr 1, s. 205-254; A. Kazhdan, L. Sherry, Some Notes on the «Scriptor Incertus de Leone Armenio», „Byzantinoslavica” 1997, nr 58, s. 110-112; A. Markopoulos, La Chronique de l'an 811 et le Scriptor Incertus de Leone Armenio: problèmes des relations entre l'hagiographie et l'histoire, „Revue des Études Byzantines” 1999, nr 57, s. 255-262; P. Stephenson, „About the Emperor Nikephoros and How he Leaves his Bones in Bulgaria": A Context for the Controversial Chronicle of 811, „Dumbarton Oaks Papers” 2006, nr 60, s. 87-109; P. Sophoulis, The Chronicle of 811, the Scriptor incertus and the Byzantine-Bulgar wars of the early ninth century, „Bulgaria Mediaevalis” 2010, nr 1, s. 381-388; L. Brubaker, J.F. Haldon. Byzantium in the Iconoclast Era, c. 660-850: A History, Cambridge 2011, s. 179-180.

4 Theophanis chronographia, AM 6303, wyd. C. de Boor, t. 1, Lipsiae 1883, s. 489, 22-490, 29;

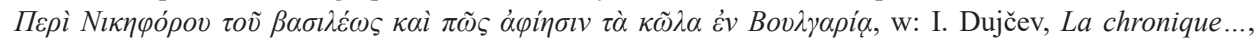
s. 210, 1-212, 40 .

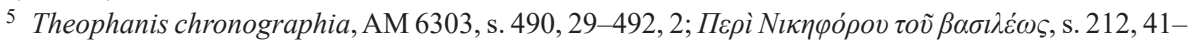
216, 97. Na temat tego starcia zbrojnego zob. m.in. В.Н. Златарски, История на българската държава през средните векове, t. 1, сzęść 1, Епоха на хуно-българското надмощчие (679-852), София 1918, s. 255-260; Щ. Атанасов, Ив. Дуйчев, Д. Ангелов, Г. Цанкова-Петкова, Д. Христов, Б. Чолпанов, Българското военно изкуство през феодализма, София 1958, s. 165-172; Д. Христов, Войнатамежду България и Византия през 811 г., „Известия на Военноисторическото дружество” 1967, nr 4, s. 6495; A. Kominis, Echi della battaglia dell'anno 811 tra Bizantini e Bulgari in testi agiografici, w: Actes du premier Congres International des Études Balkaniques et Sud-Est Européennes, Sofia, 26 âout - 1 septembre 1966, t. 3, Histoire (Ve-XVe ss.; XVe-XVIIe ss.), red. V. Tăpkova-Zaimova, S. Dimitrov, E. Sarafova, Sofia 1969, s. 313-318; С.Т. Недев, Разгромът на Никифор I Геник през 811 г., „Военноисторически сборник” 1977, nr 46.1, s. 115-127; J. Wortley, Legends of Byzantine Disaster of 811, „Byzantion” 1980, nr 50, s. 533-562; V. Beševliev, Die Protobulgarische Periode der bulgarischen Geschichte, Amsterdam 1981, s. 240-247; Д. Ангелов, Ст. Кашев, Б. Чолпанов, Българска военна история от Античността до втората четвърт на Х в., София 1983, s. 225-231; В. Бешевлиев, Крум и Никифор, „Studia 
od 378 r., a zatem śmierci cesarza Walensa (364-378) pod Adrianopolem ${ }^{6}$. Z korelacji wspomnianych przekazów źródłowych wynika, że armia bizantyńska spędziła na obszarach bułgarskich co najmniej piętnaście dni. W obu tekstach pojawiają się również wzmianki, które można łączyć ze świadomie podejmowanymi przez nią działaniami względem tamtejszego szeroko pojętego zaplecza gospodarczego, konkretnie obszarów poddanych kultywacji oraz lokalnych zwierząt hodowlanych. Dla przejrzystości wywodu i trudności związanych z ich interpretacją pozwolę sobie na zacytowanie odpowiednich fragmentów tych średniowiecznych przekazów:

\section{Teofanes:}

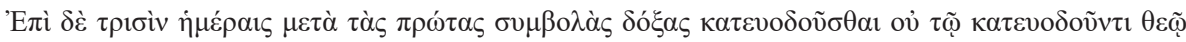

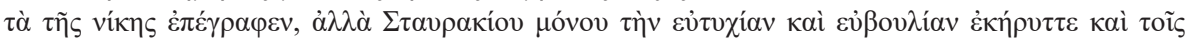

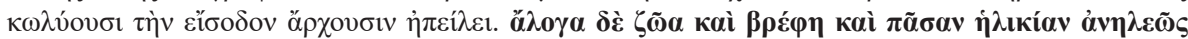

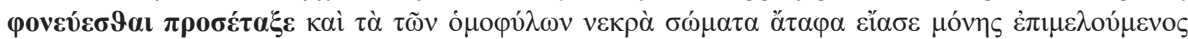

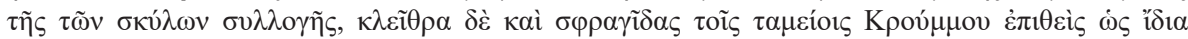

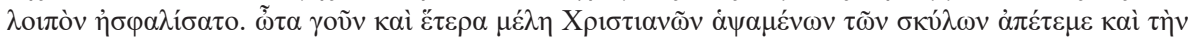

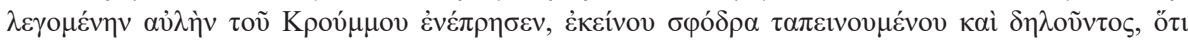

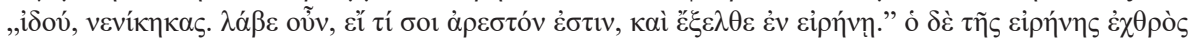

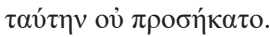

W ciągu trzech dni po pierwszych starciach, gdy powodzenie wydawało się sprzyjać, zwycięstwo przypisał nie Bogu, który przynosi powodzenie, lecz ogłaszał jedynie sukcesy i roztropność Staurakiosa, a groził archontom, którzy starali się zapobiec atakowi. Polecil bezlitośnie wymor-

Balcanica" 1983, nr 17, s. 17-26; P.E. Niavis, The Reign of the Byzantine Emperor Nicephorus I(AD 802 811), Athens 1987, s. 234-248; W. Treadgold, The Byzantine Revival 780-842, Stanford 1988, s. 168-174;

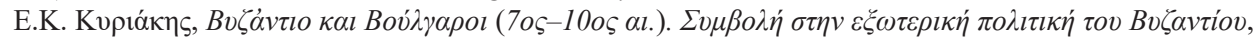

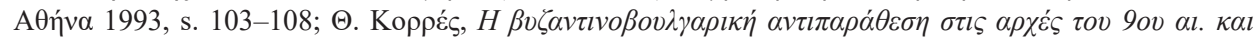

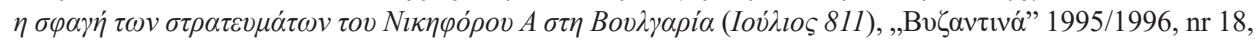
s. 167-193; В. Гюзелев, Езическа България, w: Ив. Божлов, В. Гюзелев, История на средновековна България VII-XIV век, София 1999, s. 128-131; J. Haldon, The Byzantine Wars. Battles and campaigns of the Byzantine era, Stroud 2001, ps 71-76; М.Й. Лешка, Цели похода Никифора I против болгар в 811 году, w: Byzantium, New Peoples, New Powers: The Byzantino-Slav Contact Zone, from the Ninth to the Fifteenth Century, red. M. Kaimakamova, M. Salamon, M. Smorąg Różycka, Cracow 2007, s. 55-62; К. Станев, Дървената преграда в старопланинския проход през 811 г., „История”

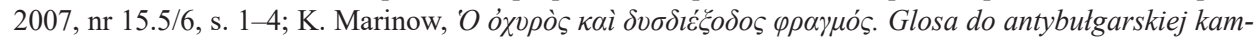
panii zbrojnej Nikefora I z 811 r., „Słupskie Studia Historyczne” 2011, nr 17, s. 9-18; P. Sophoulis, Byzantium and Bulgaria, 775-831, Leiden-Boston 2012, s. 192-216; Д. Момчилов, Маркели в похода на византийския император Никифор I Геник през 811 г. и ответния удар на Крум, „Годишник на Университет “Проф. д-р Асен Златаров”” 2011, nr 40, s. 224-230; idem, Къде Никифор I Геник преминава Източна Стара планина през 811 г. по направлението Маркели-Плиска, „Управление и образование” 2013, nr 9.4, s. 142-151; idem, Още веднъж за похода на Никифор I Геник през 811 г., w: Българско средновековие: общество, власт, история. Сборник в чест на проф. д-р Милияна Каймакамова, red. Г.Н. Николов, София 2013, s. 221-228.

6 П. Мутафчиев, История на българския народ, t. 1, Първо българско ичарство, София 1992, s. 117; F. Curta, Eastern Europe in the Middle Ages (500-1300), Leiden-Boston 2019, s. 89. O śmierci cesarza Walensa zob. m.in. H. Wolfram, History of the Goths, transl. Th.J. Dunlap, Berkeley-Los AngelesLondon 1990, s. 127-128. 
dować nieme zwierzęta, niemowlęta i ludzi w każdym wieku, ciała współplemieńców pozostawić niepogrzebane dbając tylko o zebranie łupów. Skarbce Kruma kazał zamknąć, zapieczętować i chronił je w końcu jako własne. Chrześcijan zaś, którzy próbowali tknąć łupów ukarał przez obcięcie uszu i innych części ciała; podpalił też tak zwany pałac Kruma, gdy on daremnie korzył się i wyjaśniał: „Oto zwyciężyłeś, zabierz więc, co ci się podoba i odejdź w pokoju”. Ale wróg pokoju na to nie przystał. ${ }^{7}$

\section{Anonimowa Kronika:}

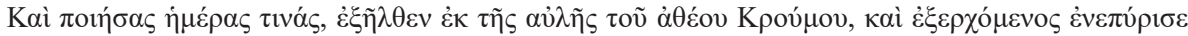

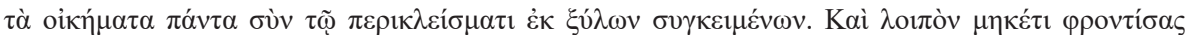

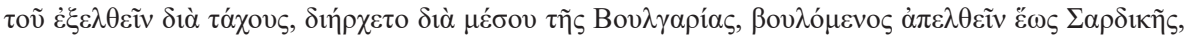

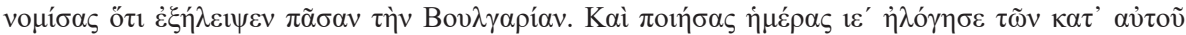

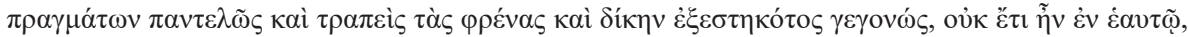

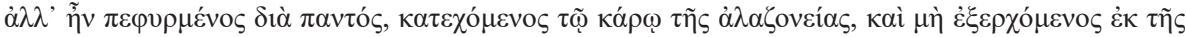

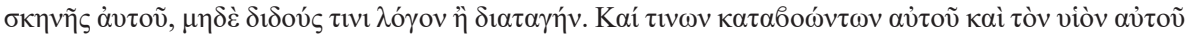

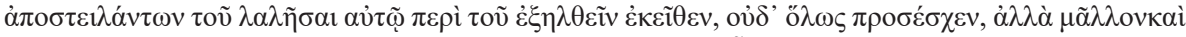

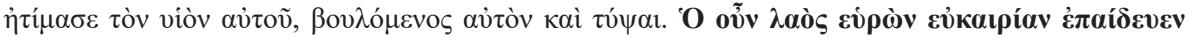

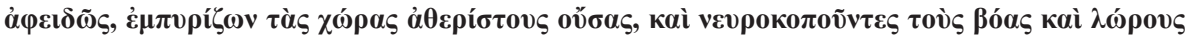

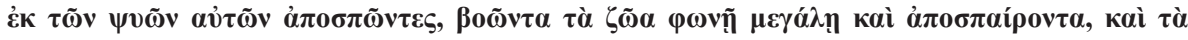

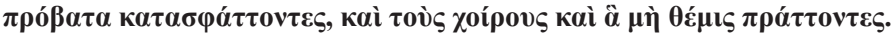

Po upływie kilku dni opuścił dwór bezbożnego Kruma i wychodząc podpalił wszystkie budynki wraz z ogrodzeniem ułożonym z pni. I nie troszcząc się o to, by wyjść pospiesznie przeszedł przez środek Bułgarii zamierzając dotrzeć do Sardiki, przekonany, że podbił całą Bułgarię. A po 15 dniach zobojętniał całkiem na swoje sprawy; zmieniony na duchu i jakby pozbawiony zdrowych zmysłów nie był już sobą, lecz całkowicie oszołomiony, obezwładniony własną pychą nie opuszczał swego namiotu, nie rozmawiał i nie wydawał poleceń. Kiedy ci, którzy wykrzykiwali przeciwko niemu wysłali jego syna, aby go nakłonił do wycofania się stamtąd, on w ogóle nie zwrócił na niego uwagi, lecz raczej go znieważył chcąc go nawet uderzyć. Wojsko zatem korzystając ze sposobności zaczęło grabić nie szczędząc niczego, podpalając pola, które nie były zżęte; podcinali ścięgna wołom, cięli pasy $z$ ich lędźwi, zwierzęta ryczały strasznym głosem i miotały się w konwulsjach, zabijali owce i świnie, czynili wszystko, co się nie godzi. ${ }^{8}$

Już pobieżny rzut oka na obie narracje pokazuje, że ich korelacja nie jest wcale taka łatwa i oczywista. Po pierwsze, w sprawie chronologii, gdyż w przypadku Teofanesa nie wiemy czy wzmiankowane polecenie cesarskie nie zostało wydane jeszcze w trakcie pierwotnego marszu na Pliskę ${ }^{9}$, gdybyśmy fakt nie grzebania poległych żołnierzy bizantyńskich złożyli na karb pośpiesznego zmierzania w kierunku stolicy bułgarskiej, jak chcą niektórzy uczeni ${ }^{10}$. Względna chronologia w obu

7 Theophanis chronographia, AM 6303, s. 490, 18-29, tłum. Alina Brzóstkowska; Testimonia najdawniejszych dziejów Stowian. Seria grecka, red. A. Brzóstkowska, W. Swoboda, z. 3 (Pisarze z VII-X wieku), Wrocław 1995, s. 73-74 (wytłuszczenia i drobna korekta przekładu moje; K.M.).

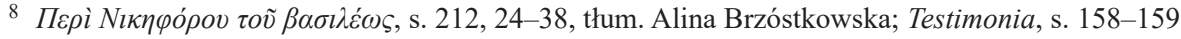
(wytłuszczenia i drobna korekta przekładu moje; K.M.).

9 Tak rozumuje Й. Андреев, Крум, w: idem, Ив. Лазаров, Пл. Павлов, Кой кой е в Средновековна България (Трето допълнено и основно преработено издание), София 2012, s. 407.

10 Testimonia, s. 111, przyp. 97 (komentarz Wincentego Swobody). 
tekstach także wydaje się różnić. U Wyznawcy zwierzęta były wybijane przed podpaleniem pałacu Kruma, w anonimowym dziełku już po tym fakcie. Także długość przebywania wojsk bizantyńskich na obszarach bułgarskich jest odmienna, gdyż z tekstu Teofanesa wynika, że armia cesarska spędziła tam nie więcej niż sześć dni, podczas gdy anonim wyraźnie podaje liczbę piętnastu tychże $\mathrm{e}^{11}$. U Teofanesa to bezpośrednio cesarz wydaje nakaz wybijania zwierząt i miejscowej ludności, w Kronice roku 811 jest to wynik jego apatii względem wydarzeń i wynikającego z niej rozluźnienia dyscypliny wśród podkomendnych. W dodatku, w tekście bizantyńskiego chronografa Stauracjusz, syn Nikefora, jak najbardziej znajduje się w łaskach u ojca, podczas gdy przekaz Kroniki jest pod tym względem wyraźnie odmienny ${ }^{12}$. Dodam również, że przekazana przez Wyznawcę informacja o niedzieleniu się przez cesarza łupami z żołnierzami i surowym karaniu ich za sięganie po nie stoi w jawnej sprzeczności z przekazem Kroniki, wedle której czynił dokładnie na odwrót, tzn. rozdawał je ${ }^{13}$. To co nam się zgadza to sama informacja o zabijaniu zwierząt (podkreślona bezlitosność tego czynu u Teofanesa wydaje się dobrze współgrać z opisem okrucieństw wobec nich podanym przez anonimowego autora) i spaleniu pałacu chana. Pomimo wskazanych wątpliwości wydaje mi się, że obaj autorzy mieli jednak na myśli te same wydarzenia. A zatem na pytanie czy istnieje możliwość pogodzenia obu narracji, także $\mathrm{w}$ interesującym mnie temacie, należy odpowiedzieć twierdząco ${ }^{14}$.

Uważam, iż różnice w obu przekazach podyktowane są m.in. inną konstrukcją narracji w obu tekstach. Anonimowy autor podaje bardziej szczegółowe informacje

11 Jak już wspomniałem wcześniej, przyjmuję taką długotrwałość przebywania armii bizantyńskiej

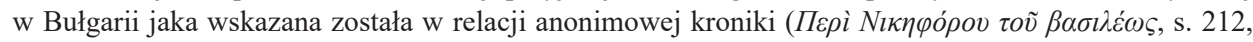
28. 44; podobnie w Testimonia, s. 179, przyp. 6 (komentarz Wincentego Swobody); В. Гюзелев, Езическа България, s. 128, 130; P. Sophoulis, Byzantium and Bulgaria, s. 199-200), ponieważ lepiej zgrywa się z planami i działaniami cesarza względem terytoriów chanatu. Pogląd ten uzasadniam w niniejszym artykule. Przeciwko temu występuje I. Dujčev, La chronique byzantine, s. 234, 238, m.in. zadając pytanie, że jeżeli przyjmiemy owe piętnaście dni, to czym zajmowałoby się wojsko cesarskie po pierwszych dwóch, trzech dniach, w trakcie których pokonało Bułgarów. Właśnie na to pytanie daję odpowiedź w swoim dalszym wywodzie.

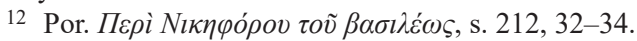

13 Ibidem, s. 212, 17-21.

14 Nie ulega wątpliwości, że udana rekonstrukcja wydarzeń związanych z bizantyńską wyprawą na Bułgarię w roku 811 zależy od zasadnej i precyzyjnej korelacji obu przekazów źródłowych, ponieważ pomimo tego, iż momentami Teofanes najwyraźniej skraca źródło, z którego czerpie swoje informacje (według niektórych uczonych tożsame z tym wykorzystywanym przez Anonima), dostarcza on danych, których nie spotykamy w Kronice. Prócz tego, wygląda na to, że był lepiej zorientowany w tym, co działo się pośród przedstawicieli arystokracji bizantyńskiej, która wzięła udział w wyprawie, czego dowodzi nie tylko opis zajścia z Byzantiosem, cesarskim służącym, jak również imienny spis możnych, którzy zginęli w Bułgarii (Anonim wspomniał o nich ogólnie, bez podawania szczegółów), lecz także jego bezpośrednie stwierdzenie, że osobiście znał osoby z otoczenia władcy (na przykład Teodozjusza Salibarasa), oraz to, że część informacji na temat kampanii mógł pozyskać od uczestników, którzy ją przeżyli (Theophanis chronographia, AM 6303, s. 489, 28-490, 4; s. 491, 24-26). Zob. pogłębione zestawienie obu przekazów źródłowych u I. Dujčev, La chronique byzantine, s. 216-254, jak i uwagi zamieszczone w P. Sophoulis, Byzantium and Bulgaria, s. 5-14, 18-19, 23-26, 32. 
na temat wydarzeń po wkroczeniu do Bułgarii, a przed klęską bizantyńską w jednej z przełęczy staropłanińskich ${ }^{15}$. Poza tym chronologia konkretnych zdarzeń jest u niego wyraźniej zarysowana. I z tego właśnie powodu jest on lepszym źródłem do ustalania następstwa zdarzeń związanych z kampanią roku 811. Natomiast cytowany passus z dzieła Teofanesa wydaje się mieć charakter zbiorczy, ogólnie omawiający sytuację w obozie bizantyńskim po wkroczeniu na tereny bułgarskie a przed finalną bitwą w górach. Zwłaszcza, że dalszy jego przekaz mówi już tylko o zajściach odnoszących się do ostatecznego starcia pomiędzy wrogimi armiami ${ }^{16}$. Nie da się, oczywiście, zupełnie wykluczyć, że mamy tu do czynienia z dwoma niezależnymi od siebie wydarzeniami, jednym na drodze ku stolicy bułgarskiej (Teofanes) i drugim zaistniałym już po jej opuszczeniu (Anonim). $Z$ drugiej strony rozdzielność obu wydarzeń jeszcze dobitniej świadczyłaby o celach bizantyńskiej wyprawy, a mianowicie niszczeniu zaplecza demograficznego i gospodarczego Bułgarii, co nie miałoby większego sensu, gdyby cesarz z góry zakładał, że inkorporuje jej terytoria w granice cesarstwa. Wówczas likwidacja siły roboczej i dobytku chanatu mijała by się z celem, gdyż szkodziłaby ekonomicznemu statusowi tych ziem w Bizancjum. Pozbawiałaby skarbu państwowego odpowiednich dochodów, a trudno uwierzyć, że władca tak dalece zainteresowany fiskusem, jakim był Nikefor, pozwoliłby sobie na takie marnotrawstwo.

15 Tradycyjnie uważa się, że chodzi o jedną z przełęczy we Wschodniej Starej Płaninie, najczęściej Wyrbicką lub Riszką; В.Н. Златарски, История, s. 258, 259; С.T. Недев, Разгромъm, s. 124-127;

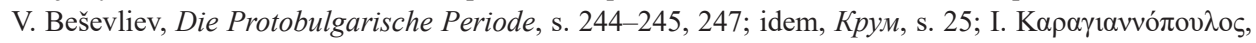

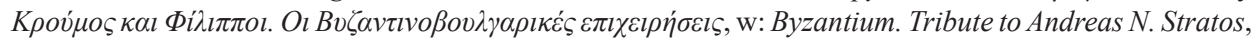
red. A.N. Stratos, t. 1 (History, Art and Architecture), Athens 1986, s. 101; P.E. Niavis, The Reign..., s. 243-244; М.Й. Лешка, Цели, s. 60, przyp. 18; F. Curta, Eastern Europe, s. 89. Zupełnie inną proprozycję, Przełęcz Trewneńską w Centralnym Bałkanie, przedstawił Ewgeni Dermendżiew (Е. Дерменджиев, Една хипотеза за похода на император Никифор I Геник в България, w: Studia protobulgarica et mеdiaevalia europensia. В чест на професор Веселин Бешевлиев, red. К. Попконстантинов, София 2003, s. 401-408).

16 Theophanis chronographia, AM 6303, s. 490, 29-492, 5; por. uwagi: S. Turlej, The collapse of the Avar Khaganate and the situation in the southern Balkans. Byzantine and Bulgarian relations in the early 9th century. The birth of Krum's power and its foundations, w: Byzantina et Slavica Cracoviensia, t. 5 , Byzantium, New Peoples, New Powers: the Byzantino-Slav Contact Zone, from the Ninth to the Fifteenth Century, red. M. Kaimakamova, M. Salamon, M. Smorąg Różycka, Cracow 2007, s. 41. Nie oznacza to wcale, że w jego narracji nie ma żadnego następstwa chronologicznego. Przeciwnie, chociaż po prawdzie koncentruje się on bardziej na tym, co stało się (a w zasadzie, co czynił Nikefor), ,w ciągu trzech dni po pierwszych starciach" niż na rygorystycznym trzymaniu się sekwencji zdarzeń. Dla przykładu, w ogóle nie wspomina o zdobyciu stolicy bułgarskiej, choć opanowanie Pliski było dlań faktem, skoro w pewnym momencie wyraźnie stwierdza, że cesarz zamknął skarbce Kruma. Zwłaszcza, że informację tę podał wraz (w tekście greckim jest to część tego samego zdania) z tą, iż bardziej troszczył się o łupy niż o grzebanie padłych w boju Rzymian, co zazwyczaj chronologicznie umiejscawia się jeszcze przed wkroczeniem armii cesarskiej do bułgarskiej stolicy. Nie zagłębiając się w kwestie chronologii przedstawionych w źródłach wydarzeń pragnę jedynie wskazać, że cesarski rozkaz wybicia zwierząt i miejscowej ludności mógł zostać wydany już po wkroczeniu do Pliski, a nie przed nim, co lepiej korelowałoby z danymi Anonima. Prócz tego trudno mi przyjąć, że spiesząc się do centrum chanatu cesarz nie grzebał swoich ziomków, a tracił czas na gromadzenie łupów z pola walki (oczywiście, nie osobiście). 
Sądzę jednak, że bardziej prawdopodobny jest fakt tożsamości obu zdarzeń (przykładowo inne wydarzenia, oprócz próśb Kruma o pokój, nie dublują się w obu tekstach), opisanych na dwa różne sposoby. W tym kontekście do Teofanesa dotarłaby jedynie wzmianka o okrucieństwie wobec zwierząt i miejscowej ludności, z pominięciem informacji o paleniu pól uprawnych ${ }^{17}$. $Z$ drugiej strony, brak informacji na temat zabijania Bułgarów w Kronice jest podejrzany, biorąc pod uwagę znacznie bardziej szczegółowy i pełny opis zdarzeń w tym źródle. Nie można wykluczyć, że poświadczenia okrucieństw względem nich należy szukać w następujących frazach z tego tekstu, a mianowicie ,grabieniu bez oszczędzania czegokolwiek” oraz ,,czynieniu wszystkiego, co się nie godzi” przez żołnierzy cesarskich, jakkolwiek byłby zaskakujący fakt, że autor koncentruje się na losie pól uprawnych i zwierząt, a nie istot ludzkich (szczególnie zaś wspomnianych przez Teofanesa niewinnych niemowląt, a w zgodzie z jednym ze znaczeń wykorzystanego przez niego rzeczownika $\tau \grave{\alpha} \beta \rho \varepsilon ́ \varphi \eta$, nawet tych znajdujących się jeszcze w matczynych łonach, co pośrednio sugerowałoby mordowanie brzemiennych kobiet) ${ }^{18}$, których bezlitosne zabijanie wybrzmiałoby znacznie bardziej oskarżycielsko. Konstatacja ta czyni ten fragment przekazu Teofanesa podejrzanym, zwłaszcza, że brzmi on dość specyficznie, ponieważ zwierzęta zostały wymienione na pierwszym miejscu, przed ludźmi, jakby były dla niego ważniejsze. Możliwe jednak, że autor stopniował występki cesarza, od najlżejszego, czyli wybicia zwierząt, do najpoważniejszego, zbezczeszczenia ciał swoich poddanych, pozbawionych pochówku. Oznaczałoby to wszakże, że okrutne pozbawienie życia ciężarnych Bułgarek lub ich nowonarodzonych dzieci nie robiły na nim takiego wrażenia, jak porzucone na łaskę losu ciała poległych chrześcijan. Taka postawa była typowa dla epoki i nie powinna nas zaskakiwać, gdyż ostatecznie chodziło o pogan i wrogów. Wymowa tego tekstu wskazuje jednakże, iż wyciągnięcie na przedni plan obrazu zabitych pociech było celowym zabiegiem, przy pomocy którego autor pragnął mocno wpłynąć na wyobraźnię i uczucia swoich czytelników. Inaczej mówiąc, samemu uważał, że czyn ten był skrajnie nieludzki i podły. Rzecz jasna, wcale nie chodziło mu o wzbudzenie współczucia względem ofiar, lecz raczej o oczernienie i kompromitację głównodowodzącego armią bizantyńską.

Powracając do kwestii wiarygodności samego twierdzenia tekst sprawia wrażenie, jakby bizantyński pisarz chciał wpierw po kolei, zaczynając od najmłodszych, wyliczać o jakich ludzi chodziło, lecz po chwili zamknął kwestię ogólnikowym twierdzeniem, iż ma na myśli tych z każdego wieku, tzn. wszystkich. Wskażę jedynie, że oryginał pozwala również frazę „w każdym wieku“ odnieść do samych tylko dzieci, tzn., że oprócz niemowląt Bizantyńczycy zabijali dzieci w każdym wieku, co czyniłoby z nich, przede wszystkim, dzieciobójców. Jednak milczenie Kroniki w tej kwe-

17 Henri Grégoire oraz Iwan Dujczew także sądzili, że wskazane zdanie Teofanesa jest niejasne a wykorzystane przez niego źródło zostało przezeń skrócone; H. Grégoire, Du nouveau sur la Chronographie byzantine, s. 422-423; I. Dujčev, La chronique byzantine, s. 241-242.

18 Zob. A Greek-English Lexicon, red. H.G. Liddell, R. Scott, Oxford 1996, s. 329. 
stii rzuca się w oczy i pozwala mi wątpić w prawdziwość twierdzenia Wyznawcy, zwłaszcza, że doskonale wpisuje się ono w konstruowaną przez niego „czarną legendę" Nikefora. Omawianą rozbieżność w opisie okrucieństw dokonywanych przez armię cesarską można ostatecznie usunąć w zupełnie inny sposób. Jest tak, ponieważ cytowane powyżej zdanie z przekazu Teofanesa można przetłumaczyć także następująco: Polecit bezlitośnie wymordować nieme zwierzęta, nowo narodzone i te w każdym

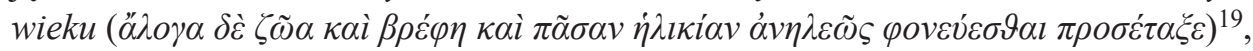
co prawie idealnie odpowiadałoby danym przekazanym przez Anonima (w takim wypadku Teofanes przemilczałby lub był niedoinformowany jedynie o spaleniu pól uprawnych). Jeżeli przyjmę tę ostatnią propozycję to synchronizacja opisów w obu źródłach, przynajmniej w odniesieniu do analizowanych passusów, staje się jeszcze pewniejsza, co oznacza, że w danym przypadku chodziło o tożsame działania, które zostały opisane w zróżnicowany sposób przez obu autorów. Jeśli natomiast skonkretyzujemy wymienione w tekście $\tau \grave{\alpha} \beta \rho \varepsilon ́ \varphi \eta ~ i ~ p r z e ł o z ̇ y m y ~ j e ~ j a k o ~ z ́ r e b a k i{ }^{20}$, a pod pozostałymi będziemy rozumieć konie w każdym wieku, otrzymamy ciekawe świadectwo celowego wybijania hodowanych przez Bułgarów wierzchowców, najprawdopodobniej wykorzystywanych przez wojowników chana w czasie wypraw wojennych. Tym bardziej że posiadamy źródła, które potwierdzają wyjątkowy status stad przeznaczonych do celów wojskowych, nie zapominając o fundamentalnej roli samej konnicy w armii bułgarskiej tamtych czasów (przypomnę jedynie, że ogon koński pełnił wówczas rolę sztandaru $)^{21}$. Wszystko to dowodziłoby tego, że Bizantyńczycy znakomicie zdawali sobie sprawę ze znaczenia tych jednostek dla potencjału militarnego państwa bułgarskiego i właśnie dlatego zdecydowali się naruszyć ich zasoby zwierzęce, by w ten sposób osłabić możliwości wojskowe wroga. Oczywiście, rozpatrywane greckie słowo można interpretować także jako określenie młodych zwierząt każdego gatunku $^{22}$. Ponieważ paralelna relacja kroniki anonimowej wymienia te gospodarskie, a więc woły, owce i świnie, jest bardziej prawdopodobne, że właśnie je miał na myśli

19 Por. przekład w The Chronicle of Theophanes Confessor. An English translation of anni mundi 6095-6305 (A.D. 602-813), with introduction and notes, by H. Turtledove, Philadelphia 1982, s. 171: He ordered horses still living (foals and beasts of all ages) mercilessly slain. Jeśli nie zaznaczono inaczej wszystkie przekłady w tekście są mojego autorstwa; K.M.

20 Zob. wskazanie tutaj, w odwołaniu nr 18.

21 J. Marquart, Osteuropäische und ostasiatische Streifzüge. Ethnologische und historisch-topographische Studien zur Geschichte des 9. und 10. Jahrhunderts (ca. 840-940), Leipzig 1903, s. 205; Nicolae I. papae epistolae, Ep. 99 (= Nicolaus capitulis 106 ad Bulgarorum consulta respondet), Cap. 33, wyd. E. Perels, w: Monumenta Germaniae Historica. Epistolae, t. 6, Karolini aevi IV, Berolini 1925, s. 580, 25 26; Щ. Атанасов, Ив. Дуйчев, Д. Ангелов, Г. Цанкова-Петкова, Д. Христов, Б. Чолпанов, Българското военно изкуство, s. 54-55, 90; V. Beševliev, Die Protobulgarische Periode, s. 359, 361, 411; Д. Ангелов, С. Кашев, Б. Чолпанов, Българска военна история, s. 146, 154; Н. Хрисимов, „Отговорите на папа Николай I до допитванията на българите" като извор за бита и ежедневието на българите по времето на княз Борис I, w: България, българите и Европа - мит, история, съвремие, t. 4, Доклади от Международна конферениия в памет на проф. дин Йордан Андреев „България, земя на блажени”, В. Търново, 29-31 октомври 2009 г., Велико Търново 2011, s. 161.

22 Zob. ponownie wskazanie tutaj, w odwołaniu nr 18 
Wyznawca. Niewykluczone jednak, iż Anonim wymienił tylko te najważniejsze i najliczniejsze, opuszczając udomowione ptactwo czy inne zwierzęta. Możliwe również, że autor Kroniki pominął informację o koniach (jest to bardziej prawdopodobne niż ominięcie wzmianki o dzieciach i poddanych chana), a wzmiankując o źrebakach Teofanes zawarł pozostałe zwierzęta $\mathrm{w}$ następującej frazie: $i$ [zwierzęta] $w$ każdym wieku, gdyż można ją przetłumaczyć także w ten sposób.

Najwyraźniej jednak inne, bizantyńskie, łacińskie i syryjskie źródła potwierdzają tradycyjnie (i filologicznie patrząc w pełni zasadnie) przetłumaczone dane z dzieła bizantyńskiego igumena. W przypadku tych pierwszych najciekawsze informacje zdają się dostarczać teksty Żywotów Mikołaja Studyty i Piotra Patrycjusza (IX w.), w obu przypadkach uczestników wyprawy roku 811, jak również Kroniki powszechnej Jerzego Kedrena (XI w.). Niestety, autor pierwszego tekstu, po tym jak donosi o zwycięstwie nad oddziałami bułgarskimi strzegącymi dostępu do chanatu, tylko za pośrednictwem dwóch słów charakteryzuje stan i działania cesarskich sił zbrojnych biorących udział w kampanii: Rzymianie oszaleli ( $\dot{\varepsilon} \mu \alpha \tau \alpha \omega \dot{\vartheta} \eta \sigma \alpha \nu)$ i chaotycznie $(\dot{\alpha} \sigma v \sigma \tau \rho o ́ \varphi \omega \varsigma)$ wtargnęli do kraju ${ }^{23}$. W drugim tekście natomiast znajdujemy enigmatyczne stwierdzenie, że lepiej będzie przemilczeć to, co stało się po początko-

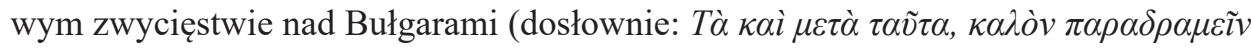
$\dot{\eta} \tau \tau \eta \dot{\tau} \tau \sigma \alpha \nu \gamma \varepsilon)^{24}$. Z punktu widzenia moich rozważań oba świadectwa posiadają nadto ogólnikowy charakter. Mogę tylko zgadywać czy za tymi sformułowaniami kryją się jakieś aluzje (szalone postępki i nieuporządkowane działania Bizantyńczyków) i pragnienie oszczędzenia (milczenie na temat tego co zaszło) czytelnikom lub słuchaczom konkretów wstydliwego postepowania ich ziomków, gdyż zupełnie pewnym jest, iż autorzy ci stosując powyższe określenia mieli na myśli przede wszystkim wydarzenia związane z tragiczną i niemniej haniebną klęską chrześcijan w bitwie z poganami. I tak, amok Bizantyńczyków był wynikiem ich pierwotnego zwycięstwa nad wojskami bułgarskimi i to pod jego wpływem pozwolili sobie na niekarne wtargnięcie do kraju swoich północnych sąsiadów, gdyż uważali, że nikt i nic nie będzie już w stanie im stawić oporu. Według pierwszego autora niedorzeczności takiego postępowania dowiodło tragiczne zakończenie kampanii: śmierć prawie całej armii i jej głównodowodzącego. Właśnie opowieści o tej wyniosłej postawie i niedocenianiu przeciwnika w związku z początkowym sukcesem, jak również rozmiarów poniesionej klęski pragnął oszczędzić publice autor drugiego z żywotów. Ergo, w ten sposób możemy deszyfrować zamieszczone w obu tekstach oceny wydarzeń, nie zakładając przy tym, iż za nimi koniecznie ukryte zostały dane odnoszące się do podjętego przeze mnie tematu. W związku z tym, że obie relacje pozbawione zostały konkretów, niestety nie mogą przysłużyć się w rozwiązaniu rozpatrywanego przeze mnie zagadnienia. $Z$ kolei

23 L. Clugnet, Histoire de saint Nicolas, soldat et moine, „Revue de l'Orient Chrétien” 1902, nr 7, s. $325,7-8$ (A).

24 Vita de S. Petro Patricio Conf., w: Acta Sanctorum, Julii, t. 1, wyd. C. Ianningo, J. Sollerio, J. Pinio, red. J. Carnandet, Parisiis et Romae 1867, s. 258 (1E). 
trzeci ze wskazanych autorów trzyma się tekstu Teofanesa z niewielkimi różnicami. Opuszcza początek oryginalnego zdania, zawierający wzmiankę o niemych zwierzętach, resztę pozostawiając w prawie dosłownym brzmieniu (z niewielkimi zmianami W szyku zdania, pojedynczymi dodatkami i zmianą przypadku gramatycznego: $\pi \tilde{\alpha} \sigma \alpha v$

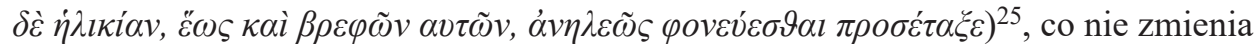
faktu, że w zasadzie wszystkie wątpliwości i możliwości związane z przekładem pierwowzoru odnoszą się również i do tekstu Kedrena.

Wśród tekstów łacińskich ponownie odnajdujemy trzy źródła, które należałoby rozpatrzyć pod kątem cytowanego passusu z dzieła Teofanesa. Chodzi o Gesta episcoporum Neapolitanorum, a dokładnie ich kontynuację napisaną przez diakona Jana (pierwsza połowa IX w.), Chronographia tripertita Anastazjusza Bibliotekarza (IX w.), jak również Kronikę Sigeberta (XI/XII w.). W pierwszym z nich twierdzi się, że starając się zawładnąć krajem Bułgarów, cesarz Nikefor nienasycenie dopuścił się wielu grabieży (multos affectos depredationibus) ${ }^{26}$, co bez wątpienia w pełni zgadza się z danymi zaczerpniętymi z naszych dwóch głównych źródeł dotyczących wyprawy z 811 r., lecz ponownie jest bardzo ogólne w swej wymowie. Mimo wszystko, ciekawa jest ta zachłanność $w$ działaniach, która $\mathrm{z}$ jednej strony uwypukla znaną już z przekazów bizantyńskich chciwość bizantyńskiego władcy, z drugiej jego zaangażowanie w to przedsięwzięcie i skalę tegoż, co niewątpliwie pochłonęło dużo wysiłku i czasu. Ze swej strony Sigebert informuje, że basileus wkroczył do Bułgarii, ale z powodu nieumiarkowania w zwycięstwie (victoriae temperare nescivit), padł zabity przez Bułgarów wraz z dużą liczbą towarzyszących mu senatorów ${ }^{27}$. Bez wątpienia, według autora władcy brakowało równowagi, tzn. pragnął wyzyskać swoje zwycięstwo ponad miarę, zadając nieprzyjacielowi więcej klęsk i strat niż dyktował to zdrowy rozsądek i dopuszczała opatrzność Boża. Innymi słowy, nie rozpoznał właściwego momentu, w którym powinien zakończyć działania wojenne, by móc bezpiecznie i zwycięsko sfinalizować ekspedycję przeciwko Bułgarom. Przeciwnie, wyobrażał sobie za wiele i dlatego w ostatecznym rozrachunku jego pewność siebie została ukarana. Zwycięstwo przemieniło się kompletną porażkę, w której zginął kwiat dworu bizantyńskiego (wspomniani senatorowie). Można by sądzić, iż za napiętnowanym tutaj brakiem umiaru kryją się, między innymi, bestialstwa względem ziem bułgarskich $\mathrm{i}$ ich mieszkańców, ale według mnie nie je miał autor na myśli, ponieważ korpus źródeł pisanych, z których czerpał swoje wiadomości Sigebert w omawianej kwestii, jest indykatywny w tej materii i pozwala odgadnąć jego rozumowanie. Wśród tych autorów należy wskazać Einharda (IX w.) i Reginona (X w.), którzy w kwestii wyprawy Nikefora I przeciwko Bułgarom zgodnie napisali, że władca ten zginął w walce

25 Georgius Cedrenus-Ioannis Scylitzae Opera, wyd. I. Bekker, t. 2, Bonnae 1839, s. 41, 18-20.

26 Gesta episcoporum Neapolitanorum, 47, wyd. G. Waitz, w: Monumenta Historiae Germanica. Scriptores rerum Langobardicarum et Italicarum saec. VI-IX, Hannoverae 1878, s. 427, 36-37.

27 Sigeberti Gemblacensis Chronographia, a. 810, wyd. D.L.C. Bethmann, w: Monumenta Historiae Germanica. Scriptorum, t. 6, wyd. G.H. Pertz, Hannoverae 1844, s. 337, 18-19. 
z nimi, lecz po wielu i znaczących zwycięstwach (post multas et insignes victorias) ${ }^{28}$. Wydaje się, że Sigebert był pod wrażeniem wspomnianych w tych źródłach licznych zwycięstw bizantyńskiego władcy i nie znając innych przyczyn (lub uważając, że nie były one decydujące), które zdecydowały o jego klęsce, wywnioskował, że doszło do tego z powodu braku umiarkowania $\mathrm{w}$ tym, skądinąd, korzystnym i udanym dla niego przedsięwzięciu.

Najważniejszym z wymienionych źródeł łacińskich jest dzieło Anastazjusza Bibliotekarza, w którym obficie korzystał on z Chronografii Teofanesa. Interesujący mnie fragment stanowi w zasadzie przekład passusu z ostatniego utworu i brzmi następująco: Rozkazał nawet [Nikefor I; K.M.] bezlitośnie zabijać nierozumne zwierzęta, niemowlęta i ludzi każdego wieku (Irrationabilia quoque animantia et infantes et omnem aetatem immisericorditer occidi praecepit) ${ }^{29}$. I jakby wszystko stawało się w pełni jasne, ponieważ tekst źródła, a przede wszystkim thumaczenie, potwierdzają informację bizantyńskiego chronografa. Nie możemy jednak zapominać, że po pierwsze, chodzi tutaj o dosłowny przekład, wręcz cytat, tzn. Anastazjusz bazuje na tym, co napisał Teofanes i nie korzysta z innych, niezależnych od tego ostatniego z przekazów, które mogłby zobiektywizować twierdzenia Bizantyńczyka. Inaczej rzecz ujmując, otrzymujemy dokładnie tę samą informację, nic nowego. Po drugie, sam łaciński przekład, w istocie potwierdza tradycyjne rozumienie Teofanesa, akceptowane przez większość współczesnych tłumaczy i uczonych ${ }^{30}$. Mimo wszystko jest tylko tłumaczeniem, a zatem, interpretacją wyjściowego tekstu ze strony Bibliotekarza, jego osobistym zrozumieniem oryginału. I po trzecie, paradoksalnie, sam łaciński passus może być interpretowany w inny sposób, współgrający z wyżej przedłożonym przeze

28 Annales Einhardi, a. 812, wyd. G.H. Pertz, w: Monumenta Historiae Germanica. Scriptorum, t. 1, Hannoverae 1826, s. 199, 25-26; Reginonis Chronicon, a. 812, wyd. G.H. Pertz, w: Monumenta Historiae Germanica. Scriptorum, t. 1, Hannoverae 1826, s. 566, 50-51. Wskazuje się, że głównym źródłem Sigeberta dla omawianego okresu była Chronographia tripertita Anastazjusza Bibliotekarza, lecz nie bezpośrednio a poprzez jedną z jej redakcji, konkretnie tzw. Historia miscella. W związku z tym, w kontekście rozpatrywanego passusu mnicha z Gembloux, jako podstawowe źródła jego informacji cytuje się właśnie te dwa utwory: С. Михайлов, П. Лунгарова, Хрониката на Зигеберт и сведенията му за българите в периода 680-820 г., „Епохи” 2017, nr 25.2, s. 449, 470, przyp. 96. Zgadzając się tą konstatacją muszę uzupełnić, że Einhard i Reginon (pierwszy z nich prawdopodobnie za pośrednictwem drugiego, ponieważ według wydawcy Sigebert z dzieł Einharda bezpośrednio znał jedynie Żywot Karola Wielkiego) także wchodziły w skład wykorzystanych przez niego źródeł; zob. Sigeberti Gemblacensis Chronographia, s. 275 (wstęp pióra Ludwiga K. Bethmanna). Wskazuję tych dwóch autorów, gdyż znacznie wyraziściej od podstawowego dla niego tekstu Historii mieszanej podkreślają oni zwycięstwa Nikefora, co mogło wpłynąć na jego własną ocenę wydarzeń.

29 Anastasii Bibliothecarii summae ac Apostolicae Sedis Chronographia Tripertita, w: Theophanis chronographia, wyd. C. de Boor, t. 2, Theophanis vitas, Anastasii Bibliothecarii Historiam Tripertitam, Disserationem de codicibus operis Theophanei indices, Lipsiae 1885, s. 329, 8-10.

${ }^{30}$ Zob. m.in. tłumaczenia w Theophanis Confessoris Chronographia, tłum. V. Beševliev, G. CankovaPetkova, wstęp i kom. idem, w: Fontes graeci historiae bulgaricae, t. 3, wyd. I. Dujčev, G. Cankova-Petkova, V. Tăpkova-Zaimova, L. Jončev, P. Tivčev, Sofia, [s. a.], s. 282; Testimonia, s. 73, oraz The Chronicle of Theophanes Confessor. Byzantine and near East History AD 284-813, translated with Introduction and Commentary by C. Mango and R. Scott with the assistance of G. Greatrex, Oxford 1997, s. 491. 
mnie tłumaczeniem fragmentu Teofanesa, gdyż łacińskie infantes oznacza m.in. małe, niedojrzałe, młode, jak również i płody w tonach matek, co odnosi się zarówno do ludzi, jak i do zwierząt, a nawet roślin ${ }^{31}$.

Przedstawicielką trzeciej grupy źródeł jest Kronika Michała Syryjczyka (XII w.), w której twierdzi się co następuje: Nikefor, cesarz Rzymian, maszerowat przeciwko Butgarom. Odnióst zwycięstwo i zabit wielu z nich. Dotart do ich stolicy, zdobyt ja $i$ zdewastowat. Jego zdziczenie osiagnęto taki stopień, że przyprowadzit ich małe dzieci, położyt je na ziemi i przejeżdzal po nich saniami/walcami młockarskimi (Sa sauvagerie alla à ce point qu'il fit apporter leurs petits enfants, les fit étendre à terre et fit passer dessus des rouleaux à battre le grain $)^{32}$. Świadectwo jakobickiego patriarchy dobrze koreluje z danymi z naszych głównych źródeł, zwłaszcza z narracją Teofanesa. Jest tam mowa o pierwotnych zwycięstwach nad Bułgarami, opanowaniu stolicy chana i jej spustoszeniu (spaleniu), a przede wszystkim jest informacja o nieludzkim (dosłownie, skoro przyrównany został do dzikich zwierząt) postępowaniu cesarza i strasznym losie niemowląt. Na pierwszy rzut oka nawet konstatacja o zabiciu wielu Bułgarów mogłaby połączyć się z Teofanesową wzmianką o wybijaniu ludzi w każdym wieku ${ }^{33}$. Takie wrażenie może powstać tylko podczas pobieżnego odczytu tekstu, gdyż wskazana informacja została wyraźnie podana w kontekście zwycięstw bizantyńskich ${ }^{34}$, tzn. starć wojennych z oddziałami bułgarskimi, a nie w związku z dodatkowym uśmiercaniem miejscowej ludności, na co nalega Wyznawca. Niemniej, inny syryjski tekst, niezależnie od Michała relacjonujący ich wspólne źródło do tych wydarzeń, a mianowicie tzw. Anonimowa syryjska kronika do roku 1234, po tym jak zgodnie z Syryjczykiem informuje o rozbiciu wojsk bułgarskich i wybiciu wielu z ich żołnierzy dodaje, iż także po zdobyciu miasta stołecznego Bułgarów, Nikefor I zabił różnych ludzi. Nic jednak nie podaje o jakichkolwiek dzieciach, a tym bardziej o sposobie ich uśmiercania ${ }^{35}$. Tak czy inaczej, twierdzenie Teofanesa, szczególnie to dotyczące dzieci, dobitnie zostało potwierdzone przez samego Michała, a tym samym, jak się wydaje, uzupełnia przekaz Bizantyńczyka na temat postępków cesarza, bazując przy tym na innych źródłach.

31 Stownik tacińsko-polski, red. M. Plezia, t. 3, Warszawa 2007, s. 135-136.

32 Chronique de Michel le Syrien, patriarche jacobite d'Antioche (1166-1199), XII, Chap. V, wyd. i thum. J.-B. Chabot, t. 3, Paris 1905, s. 17; thum. K.M. Przegląd innych wschodnich źródel, które dostarczają bądź bardzo ogólną informację w poruszanym temacie, bądź stanowią wariant przekazu Michała u P. Sophoulis, Byzantium and Bulgaria, s. 41-43; К.С. Крьстев, Арабски и сирийски извори за управлението на хановете Крум (след 796-814) и Омуртаг (814-около 831), w: Българско иарство. Сборник в чест на 60-годишнината на дои. д-р Георги Н. Николов, red. А. Николов, София 2018, s. 284-294.

33 Tak, na przykład, odczytali jego tekst autorzy dwóch wersji średnioarmeńskiego przekładu jego Kroniki: П. Голийски, Древните и средновековните българи в сирийските и сирийско-арменските извори, „Епохи” 2019, nr 27.2, s. 445.

${ }^{34}$ Por. Chronique de Michel le Syrien, t. 3, s. 17, przyp. 4 (komentarz Jeana-Baptista Chabota).

35 Anonymi auctoris Chronikon ad. A.C. 1234 pertinens II, trans. A. Abouna, ed. J.-M. Fiye, Louvain 1974, s. 4. 
Czy jednak rzeczywiście sprawy tak się mają? Dla rozpatrywanego przeze mnie przedziału chronologicznego, początku IX w., a w szerszym ujęciu dla okresu 582-842 (czyli od czasów cesarza Maurycjusza do tych Teofila), opisanego w księgach X-XII, Syryjczyk bazował, głównie, na Kronice Dionizjusza z Tel-Mahre (IX w.), jednego ze swoich poprzedników na tronie patriarszym, jak również na dziele historycznym Ignacego z Meliteny (XI w.) ${ }^{36}$. Nie ma wątpliwości, że pierwszy z nich stanowił jego główne źródło wiedzy, jakkolwiek według niektórych badaczy prawdopodobnie znał go za pośrednictwem tekstu wspomnianego metropolity meliteńskiego ${ }^{37}$. Z uwagi na to, że oba wcześniejsze utwory nie zachowały się ${ }^{38}$ nie wiemy, czy ich autorzy znali dzieło Teofanesa, a tym samym, za ich pośrednictwem, czy znał je Michał. Poglądy uczonych w tej materii są rozbieżne. I tak, dla przykładu, Günter Christian Hansen uważa, że tekst Teodora Lektora (VI w.) Syryjczyk znał dzięki lekturze Teofanesa ${ }^{39}$, co znacznie podwyższałoby prawdopodobieństwo wykorzystania tego ostatniego jako źródła do wyprawy roku 811 . W ostatnim czasie podobne konstatacje zostały jednak poddane gruntowej krytyce przez Andy'ego Hilkensa, który zestawiając teksty Lektora, Teofanesa, Michała Syryjczyka oraz Anonimowej syryjskiej kroniki do roku 1234 wykluczył możliwość bezpośredniej znajomości Teofanesowego utworu m.in. przez Syryjczyka. Nie odmawiając bliskich miejscami podobieństw pomiędzy ich przekazami uczony ten zaproponował hipotezę, zgodnie z którą obaj (tzn. Teofanes i Michał) pozyskali część informacji dotyczących okresu IV-VI w. od nieznanego bizantyńskiego autora żyjącego pomiędzy początkiem VII a początkiem IX stulecia, który przygotował wyciąg $\mathrm{z}$ historii kościelnych (w tym z Teodora Lektora). Rzecz jasna, Michał dokonał tego za pośrednictwem Dionizjusza lub raczej pewnego anonimowego autora syryjskiego tworzącego pomiędzy połową VII a drugą połową XII w., według wskazanego uczonego identycznego z Ignacym z Meliteny ${ }^{40}$. Jak już zostało wspomniane dla okresu 582-842, Michał osobiście lub poprzez tego anonimowego historyka (Ignacego Meliteńskiego?) opierał się na świadectwie Dionizjusza

36 J.-B. Chabot, Introduction, w: Chronique de Michel le Syrien, t. 1, Paris 1899, s. XXV, XXXIXXXIV; R.G. Hoyland, Seeing Islam as Others saw It: A Survey and Evaluation of Christian, Jewish and Zoroastrian Writings on Early Islam, Princeton 1997, s. 417-418; П. Голийски, Древните и средновековните българи, s. 418, 428-429.

37 A. Hilkens, The Anonymous Syriac Chronicle up to the Year 1234 and its Sources. Proefschrift voorgelegd tot het behalen van de graad van Doctor in de Geschiedenis. Universiteit Gent, Faculteit Letteren \& Wijsbegeerte 2014, s. 319-320, 353, 355, 362; https://biblio.ugent.be/publication/4381496/ file/4381498.pdf [dostęp: 23-24.08.2020]. Dysertacja powyższa wydana została drukiem w roku 2018, w prestiżowej serii Orientalia Lovaniensia Analecta: Bibliotheque de Byzantion, $\mathrm{nr}$ 18, lecz, niestety, podczas pisania niniejszego tekstu monografia ta była poza moim zasięgiem. Korzystam natomiast z jej wersji pierwotnej.

38 Po Dionizjuszu ostał się tylko jeden fragment pisma antyheretyckiego: A. Hilkens, The Anonymous Syriac Chronicle, s. 355.

39 Zob. A. Hilkens, The Anonymous Syriac Chronicle, s. 286, 288-292, 317, 425; por. R.G. Hoyland, Seeing Islam, s. 418.

40 A. Hilkens, The Anonymous Syriac Chronicle, s. 283-353, 425-426. 
z Tel-Mahre. W tekście Kroniki wprost zacytowana została informacja, według której dla interesującego mnie okresu z początku IX stulecia Dionizjusz czerpał dane m.in. z dzieła konstantynopolitańskiego autora, żyjącego w czasach panowania czterech cesarzy, znakomicie obeznanego z ich dokonaniami, mając przy tym na myśli następujących władców: Stauracjusza (811), Michała I (811-813), Leona V (813-820) i (prawdopodobnie) Nikefora I. ${ }^{41}$ Pisarz ten pozostaje nieznany, lecz Hilkens charakteryzuje go jako bardzo dobrze zorientowanego w problematyce relacji bizantyńsko-bułgarskich, przy czym kategorycznie probułgarsko nastawionego i wyraźnie nieprzychylnego ostatniemu z wymienionych imperatorów, identyfikując go z ,pewnym pisarzem chalcedończykiem, który oskarżał Nikefora o wiele rzeczy“442, wzmiankowanym przez Michała w innym miejscu XII-ej księgi jego dzieła. Pomimo oczywistej identyfikacji uczony ten odrzuca możliwość, by chodziło o Teofanesa Wyznawcę z powodu tego, iż większość informacji podanych przez Michała nie pojawia się w tekście tego ostatniego ${ }^{43}$.

Konstatacja ta rodzi jednak szereg pytań i wątpliwości: 1. Zacytowany powyżej passus z tekstu Syryjczyka prawie idealnie pokrywa się z twierdzeniami Teofanesa. Różnica sprowadza się do bardziej szczegółowego opisania losu dzieci. Z drugiej strony Michał opuścił niektóre informacje występujące w narracji Teofanesa; 2. Skąd jednak indziej historyk syryjski zaczerpnąłby wzmiankę o uśmierceniu niemowląt, skoro nie znamy żadnego autora, czy to bizantyńskiego, czy też innego, który wzmiankowałby o tym bezpośrednio (czy nawet pośrednio), a który nie opierałby się na narracji Wyznawcy (innymi słowy, nie przejął jej od niego właśnie). Tym bardziej że poza Teofanesem i źródłami bazującymi na nim nigdzie indziej prócz w historiografii syryjskiej i tekstach z niej korzystających informacja ta nie występuje. Odrzucenie Wyznawcy jako źródła tej informacji rzeczywiście sugeruje, że i on sam musiał przejąć to świadectwo z innego przekazu, najprawdopodobniej znanego Michałowi lub jego syryjskiemu tekstowi wyjściowemu. Jednkże właśnie dla lat 810-813 bizantyński chronograf pozostaje naszym najważniejszym oryginalnym autorem, ponieważ był współczesny wydarzeniom i mógł wykorzystywać ustnie świadectwa uczestników przynajmniej części wydarzeń. Rzeczywiście przeszkodą w identyfikacji Teofanesa z anonimowym źródłem Dionizjusza jest rok, na którym zakończył on narrację Chronografii, mianowicie $813^{44}$, co wykluczałoby ją jako podstawę do poznania panowania Leona V. Z drugiej jednak strony, mimo wszystko, Wyznawca wzmiankuje jego wstąpienie na tron jak również wydarzenia związane z działalnością chana Kruma pod murami Konstantynopola, które miały miejsce w początkach rządów tego imperatora ${ }^{45}$, a w dodatku samemu dożywa prawie do końca jego rządów, gdyż

41 Chronique de Michel le Syrien, XII, Chap. XV, t. 3, s. 70-72.

42 Ibidem, XII, Chap. V, t. 3, s. 16.

43 A. Hilkens, The Anonymous Syriac Chronicle, s. 358-359.

44 W. Treadgold, The Middle Byzantine Historians, s. 39.

$45 \mathrm{Na}$ ten temat zob. szczegółowo В.Н. Златарски, История, s. 270-275; M.J. Leszka, Leon V $i$ chan Krum $w$ świetle fragmentu Chronografii (AM 6305) Teofanesa Wyznawcy, „Przegląd Nauk 
umiera w 818 r.; 3. Oczekiwanie, że Michał Syryjczyk, wiernie będzie przekazywał tekst, na którym się opierał, w danym wypadku autora bazującego na przykład na Teofanesie, jest zwodnicze, gdyż wiemy, iż opuszcza on partie tekstów, skraca (czasami jednym zdaniem kwituje dłuższe ich fragmenty), parafrazuje, redaguje i uzupełnia swoje źródła ${ }^{46}$. Nie możemy wykluczyć, że właśnie w ten sposób potraktował także fragment z Dionizjusza poświęcony konfliktowi bizantyńsko-bułgarskiemu z 811 r., w którym znalazły się również dane o postępowaniu Nikefora I Genika wobec najmłodszych poddanych bułgarskiego władcy. Podobnie przyjąć można, że wprowadził dodatkowe dane do informacji przekazanych przez tekst pierwotny, z którego korzystał. Możliwe również, iż świadectwo Teofanesa znalazło się w tekście Dionizjusza, a za jego pośrednictwem także w narracji Michała, dzięki wspomnianemu bizantyńskiemu anonimowi, piszącemu w czasach owych czterech basileusów, jeżeli zaakceptujemy pogląd Hilkensa, ponieważ nie ma żadnego dowodu na to, że autor ten nie pisał swego dzieła już po czasach Teofanesa oraz że nie przejął od tego ostatniego chociażby wyłącznie wiadomości o losie bułgarskich potomków. Ważna jest także konstatacja, że narracja Michała znacząco różni się od przekazu Bizantyńskiej kroniki roku 811, co oznacza, iż Syryjczyk z całą pewnością nie przejął opisu kampanii bizantyńskiej przeciwko Bułgarom z tego źródła.

Wszystko to prowadzi mnie do wniosku, że historia z okrutnie potraktowanymi dziećmi występująca w tekście syryjskiego patriarchy prawdopodobnie została przejęta od Teofanesa, oczywiście pośrednio. Cytowanemu fragmentowi odpowiada, z niewielkimi zmianami, także i tekst Bar Hebraeusa (XIII w.), kontynuatora Michała, w którym twierdzi się, że dzieci były miażdżone nie przyrządami do młócki, lecz ciężkimi wozami (heavy waggons) ${ }^{47}$. Badacze podkreślają, że biorąc pod uwagę fakt, iż ten ostatni autor ściśle trzymał się tekstu swojego sławnego poprzednika, tego typu odstępstwa można interpretować jako przejaw jego osobistej inwencji, swego rodzaju swobody lub niezależności z jego strony ${ }^{48}$. Jego przykład wskazuje, że i sam Michał, lub wcześniej Dionizjusz, dodali swój własny komentarz do narracji Teofanesa (ewentualnie innego greckiego źródła?), konkretnie ten dotyczący sposobu uśmiercenia bułgarskich potomków. Innymi słowy, i w tym przypadku chodziłoby o swoistą „swobodę" syryjskiego autora, wynikającą najprawdopodobniej z moralnego szoku (nieprzypadkowo nazywa on to zdziczeniem, barbarzyństwem) związanego z wieścią, że Nikefor w pełni świadomie nakazał zabijać niemowlęta. Biorąc pod uwagę, że chodzi o autora kościelnego całkiem możliwe, że ten występek cesarza kojarzył mu się z czynem króla Heroda I Wielkiego (37-4 p.n.e.), który według przekazów ewangelicznych (Mt 2,16-18) rozkazał zabić wszystkie dzieci w wieku do

Historycznych" 2007, nr 6.1-2, s. 109-117.

46 R.G. Hoyland, Seeing Islam, s. 418; A. Hilkens, The Anonymous Syriac Chronicle, s. 361-362.

47 The Chronography of Gregory Abu'l-Faraj, the Son of Aaron, the Hebrew Physician, commonly known as Bar Hebraeus (1225-1286), X, translation, introduction, appendix, index by E.A. Wallis Budge, t. 1, English Translation, Amsterdam 1976 (reprint z 1932 r.), s. 124.

48 П. Голийски, Древните и средновековните българи, s. 420. 
dwóch lat w Betlejem i jego okolicach ${ }^{49}$. A przecież człowiek takiego pokroju musiał być taki niemoralny, że nie mógł zadowolić się jedynie samym faktem uśmiercenia noworodków (co samo w sobie było karygodne), lecz z całą pewnością musiał się nad nimi pastwić, zadając im straszliwą śmierć w sposób niepojęty dla cywilizowanych ludzi (szczególnie zaś chrześcijan, tym bardziej iż samemu się nim mienił!), najprawdopodobniej czerpiąc z tego prymitywną satysfakcję. Dodam, że informacja o wykorzystywaniu tzw. sani bądź walców młockarskich w rolnictwie występuje także w tekstach biblijnych, m.in. w Księdze Izajasza 28, 27 oraz 41, 15, choć we wskazanych fragmentach nie ma związku z zastosowaniem zaproponowanym przez syryjskiego kronikarza, jakkolwiek w drugim z przywołanych wersetów odwołanie do młócki ma charakter pozorny, gdyż za pomocą tej metafory autor chciał wskazać jej uboczny skutek, a mianowicie roztarcie czegoś (u niego gór) na drobne kawałki ${ }^{50}$. Zauważyć też wypada, iż wzmiankowane przez niego użycie narzędzi rolniczych stanowić może daleką reminiscencję niszczenia bułgarskich pól uprawnych przez wojsko cesarskie. Można by rzecz, że Michał skonstruował w ten sposób obraz niejakiej farsy bądź karykatury działalności rolniczej, konkretnie zaś oddzielania ziarna od plew. W ten sposób narzędzia, które miały służyć powszechnemu dobru, czyli wspieraniu czy utrzymywaniu ludzkiego życia (w końcu z otrzymanego ziarna wytwarzano wpierw mąkę, a następnie „chleb powszedni”, czyli podstawę ówczesnej diety), stały się instrumentami kaźni, zadawania śmierci, a zatem czymś zupełnie przeciwnym do pierwotnego celu, w jakim je wytworzono. Fakt ten, postępowanie przeciwne powszechnie obowiązującym standardom, raz jeszcze dobitniej podkreślał szaleństwo cesarskiego czynu. Oczywiście, nie można wykluczyć, że tę konkretną informację o sposobie zabijania „niewiniątek” Michał przejął z całkiem innego źródła, które nie przetrwało. A jeżeli utwór ten był niezależny od opowieści Teofanesa, a ona od niego, to oznaczało, że skrajnie nieludzki rozkaz bizantyńskiego władcy byłby mocno potwierdzony. Jednakże ważniejszy jest fakt, że bez względu na to skąd historiografia syryjska przejęła to twierdzenie, od Teofanesa lub z innego źródła, wyraźnie potwierdza ona tradycyjny przekład rozpatrywanego passusu z dzieła Wyznawcy. Wypada jednak powtórzyć, że nie wyklucza to zupełnie zaproponowanego powyżej nowego rozumienia tego fragmentu Chronografii, gdyż może stanowić wyłącznie interpretację jego przekazu ze strony historyków syryjskich, którzy nie wzięli pod uwagę innej możliwości tłumaczenia tekstu Bizantyńczyka, zarówno Teofanesa jak i domniemanego Anonima.

Ekskurs poświęcony fragmentowi Teofanesa dotyczącemu losu niemowląt i ludzi w każdym wieku, jak również innym przekazom, które mogłyby potwierdzać

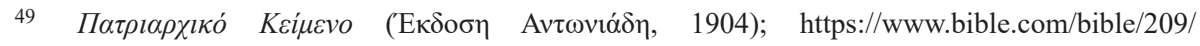
MAT.2.BYZ04 [dostęp: 22.08.2020 r.]. Całkiem prawdopodobne jest, że z tego samego motywu skorzystał także Teofanes (jeżeli naprawdę miał na myśli w swoim tekście małe dzieci), by skompromitować cesarza w oczach swoich czytelników, z nadzieją, iż skojarzą znaną historię ewangeliczną.

50 Zob. Septuaginta. Id est Vetus Testamentum grecae iuxta LXX interpretes, wyd. A. Rahlfs, przejż. R. Hanhart, t. 2, Libri poetici et prophetici, Stuttgart 2006, s. 602, 621. 
jego twierdzenie, nie ma na celu kategorycznego podważenia tej wiadomości. Tak jest, ponieważ ogólnoprzyjęty przekład tego zdania jest w pełni przekonujący, zarówno z filologicznego jak i logicznego punktu widzenia. Zazwyczaj bowiem w czasie trwania działań zbrojnych giną nie tylko żołnierze, bezpośrednio zaangażowani w walkę, lecz również zróżnicowana wiekiem ludność „cywilna” danego kraju, która pada ofiarą posuwającej się przez jego terytorium wrogiej armii. W trakcie trwania takich wypraw akty przemocy nie są wyjątkiem, dlatego, ogólnie rzecz biorąc, twierdzenie Teofanesa odpowiada rzeczywistości. Moje rozważania mają jednak za zadanie pokazać, iż tradycyjne thumaczenie i związana z nim interpretacja wydarzeń nie są jedynymi obowiązującymi, co z kolei otwiera nowe kierunki w rekonstrukcji zdarzeń z $811 \mathrm{r}$. Wydaje się również, że lepiej łączą one ze sobą dane z obu podstawowych bizantyńskich źródeł, niwelując różnice między nimi. Tak jest również dlatego, że znając stosunek Teofanesa do basileusa, klarownie wyłożony w Chronografii przy okazji opisywania zupełnie innych wydarzeń, podejrzewam, że wzmianka na temat noworodków nie jest niczym więcej niż retorycznym wyrazem ${ }^{51}$ jego nienawiści względem Nikefora i zabiegiem mającym na celu wzbudzenie niechęci do cesarza wśród odbiorców jego dzieła. Nie wierzę bowiem, by cesarz świadomie nakazał uśmiercać małe dzieci (Teofanes), tym bardziej zaś zorganizował okrutny spektakl z narzędziami młockarskimi i marnował swój czas napawając się dziecięcym cierpieniem, jak również własnym zezwierzęceniem i barbarzyństwem (Michał Syryjczyk). Jak więc należy odczytać przekazy obu bizantyńskich autorów, Wyznawcy oraz autora anonimowej kroniki? Przed udzieleniem odpowiedzi na to pytanie należy spojrzeć na to, co chcieli przekazać potomnym oni sami.

W narracji Wyznawcy Nikefor z premedytacją nakazuje nieludzkie traktowanie ludzi i zwierząt. Jest on zatem świadomie odpowiedzialny za te czyny i los ofiar. Nie dość, że rozkazuje swoim żołnierzom dokonywać tak haniebnych postępków, to jeszcze jest wobec nich skąpy, bez serca, nie wykazuje się oczekiwaną od władcy filantropią, która objawiała się najczęściej w rozdawnictwie pieniędzy, a w tym konkretnym przypadku nabytych dzięki zdobytym skarbcom bułgarskiego władcy ${ }^{52}$. Skąpstwo i umiłowanie pieniędzy były mu zresztą często przypisywane, a to ze względu na twardą politykę fiskalną, którą zwykł był realizować (przed wstąpieniem na tron był w końcu odpowiedzialny za skarb cesarski $)^{53}$. Teofanes, skądinąd, kon-

51 Doniesienie o wybiciu „niemowląt i ludzi w każdym wieku“ przypomina poniekąd wyrażenie idiomatyczne, oznaczające po prostu śmierć wielu ludzi. W związku z tym należy przypomnieć, że pisarze bizantyńscy stosowali podobne wyrażenia, na przykład, by desygnować wielkie zwycięstwo lub zadanie wrogowi druzgocącej klęski, zob. Theophanis Continuati, I, 13, wyd. I. Bekker, Bonnae 1838, s. 25,

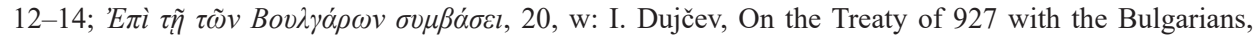
"Dumbarton Oaks Papers" 1978, nr 32, s. 282, 436. Rzecz jasna, w tekście Teofanesa podobny idiom pod adresem Nikefora Genika pozbawiony byłoby swojej pozytywnej wymowy.

52 Na temat cesarskiej filantropii zob. D.J. Constantelos, Byzantine Philanthropy and Social Welfare, New Brunswick-New Jersey 1968, s. 43-61, 111-136.

53 Por.m.in. Theophanis chronographia,AM6301,s.485,20-22;AM6303, s. 489,21-24; s. 491,29-31. 
centruje się właśnie na tym fakcie, podkreślając, że bardziej zależało mu na zbieraniu łupów niż na grzebaniu poległych w boju ziomków, pomimo tego, że już od starożytności niepogrzebanie towarzyszy padłych na polu bitewnym uważali Grecy za szczególne przewinienie moralne (zniewagę wobec zmarłych, pohańbienie ich i złamanie prawa ustanowionego przez bogów), ściągające na tak postępujących boską klątwę ${ }^{54}$. Niemniej dobitnie świadczy o tym stosunek do znalezionych skarbów Kruma, które cesarz traktował i chronił jak swoje osobiste dobro, a także brutalne obchodzenie się z własnymi żołnierzami, którzy odważyli się zatrzymać cokolwiek z nabytych łupów. Symptomatyczne jest również podkreślenie przez autora, że wybijane zwierzęta były nieme, dzieci to noworodki, a wśród zabitych z każdego wieku (jeżeli przyjmiemy tradycyjny przekład tego fragmentu) niewątpliwie na pierwszym miejscu miał na myśli starców. W ten sposób Teofanes pragnął wyraziście pokazać jak bezlitosny i nikczemny jest władca bizantyński. Przecież nakazywał on mordować bezbronnych, którzy nie byli w stanie bronić się, nie tylko fizycznie (osoby podeszłe wiekiem), lecz i werbalnie, gdyż nie potrafili nawet błagać o zmiłowanie (zwierzęta i niemowlęta). W całym tekście cesarz przedstawiony został jako człowiek okrutny, chciwy i uzależniony od dóbr materialnych, nie liczący się z nikim, nawet z Najwyższym. Wróg pokoju i wszystkiego, co dobre i wzniosłe. Morał z takiej jego postawy i takiego postępowania klarownie wypływa $\mathrm{z}$ opowieści bizantyńskiego autora. Basileus, a pośrednio z jego powodu także jego poddani, którzy również mogą być zaliczeni w poczet jego ofiar (w końcu przecież tak właśnie rozumował sam Teofanes!) ${ }^{55}$, został ukarany z powodu swojej arogancji i bezbożności.

Tekst Kroniki także obarcza Nikefora odpowiedzialnością za sytuację zaistniałą w wojsku, z tym, że ewidentnie kładzie to na karb zaniechania ze strony cesarza, a nie świadomie wydawanych przez niego rozkazów. Tutaj władca nie kieruje armią źle, lecz nie robi tego w ogóle. Brak zdecydowania z jego strony doprowadził do rozprężenia w szeregach jego żołnierzy, którzy zaczęli dopuszczać się różnorodnych

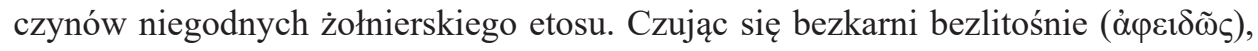
co odpowiada określeniu niemiłosiernie (ảvๆ $\lambda \varepsilon \tilde{\omega} \varsigma$ ) użytemu przez Teofanesa, grabili wszystko na swej drodze. Punkt widzenia anonima jest w pełni klarowny. Chodzi w zupełnie bezmyślne, nieuzasadnione działania wojska, motywowane lub wzbudzone niskimi instynktami, które miały na celu sianie zniszczenia dla niego samego. W ten sposób armia stawała się narzędziem niszczenia, chaosu, barbarzyństwa, które zastąpiły uporządkowane i uprawiane (tutaj przez Bułgarów) - świat, życie oraz przestrzeń. Żołnierze bizantyńscy przynieśli śmierć w miejsce dotychczasowego życia, ale nie chodziło o uzasadniony i zrozumiały koniec na polu bitewnym, lecz o pastwienie się nad bezbronnymi zwierzętami i polami uprawnymi. A zatem uczyn-

54 Por. Aľas, w: Sophoclis Tragoediae, t. 1, Aiax, Electra, Oedipus rex, wyd. R.D. Dawe, Leipzig 1984, s. 38, 1087-1092; s. 39, 1129-1131; s. 40, 1154-1155; s. 45, 1304-1307; s. 46, 1332-1345; s. 48, 1381-1399; A. Lesky, Die tragische Dichtung der Hellenen, Göttingen 1972, s. 187.

55 Zob. Theophanis chronographia, AM 6303, s. 491, 3-492, 5. 
ki, które nie mogły im przynieść żadnej sławy. Nieprzypadkowo autor podkreśla, że zboże nie było jeszcze zebrane z pól, chcąc w ten sposób dać do zrozumienia, iż żołnierze niszczyli po drodze wszystko, co żywe, uprawiane i przynoszące plony, pozbawiając $w$ ten sposób miejscowej ludności pożywienia. Szczególnie jaskrawy jest opis losu pochwyconych zwierząt. Bizantyńczycy nie pozbawiali je po prostu życia, w możliwie najszybszy i najmniej bolesny sposób, lecz znęcali się nad nimi, okrutnie je torturując i sprawiając im ogromne cierpienia. Podcinanie ścięgien uniemożliwiało zwierzętom poruszanie się i pozbawiało je możliwości ucieczki przed oprawcami, wydłużając jednocześnie ich życie, a tym samym męki. Dodatkowo towarzyszył im niewyobrażalny ból spowodowany zdzieraniem na żywo skóry z najdelikatniejszych części ciała (krocza, pachwin, lędźwi). Tak potraktowane woły ryczały strasznym głosem (ciekawe jest zestawienie z Teofanesową wzmianka o ich bezgłosie) i zdychały (dosłownie: umierały/miotały się w konwulsjach). Prócz tego żołnierze wybijali owce i świnie, które wraz z wołami stanowiły najważniejsze zwierzęta hodowane przez miejscową ludność. Sczegółowy opis tych poczynań miał na celu ich zupełną dyskredytację. Anonim nalega, że armia czyniła to, co się nie godzi. Winę za taką postawę żołnierzy ponosił sam cesarz, który odpowiedzialny był za kierowanie, pouczanie i kontrolę wielotysięcznego wojska. Nikefor jawi się więc jako władca, a konkretnie dowódca słaby, nie umiejący zarządzać armią, nie rozumiejący czego od niego się oczekuje i jakie skutki może mieć bierna postawa głównodowodzącego. Przekonany, że odniósł już pełne zwycięstwo nad wrogami, oszołomiony sukcesem i pełen pychy, wiary we własne możliwości, pozwala armii błąkać się bez celu po ziemiach bułgarskich, nie reagując nawet na wezwania ze strony podwładnych do zaangażowanego kierowania kampanią. Nie wyczuwał (sic!), a o czym autor źródła już wiedział, że powinien jak najszybciej opuścić terytoria bułgarskie, gdyż jego niezdecydowanie i niepotrzebne tracenie czasu dało przeciwnikom sposobność do regeneracji sił i zasobów ludzkich oraz przejęcia inicjatywy, podczas gdy jego własne oddziały coraz bardziej rozluźniały dyscyplinę i traciły ducha bojowego.

W ocenie obu przekazów pamiętać należy o dwóch istotnych faktach. Po pierwsze, obaj ich autorzy byli skrajnie nieprzychylni Nikeforowi I, który raczej nie należał do władców cieszących się dobrą prasą ${ }^{56}$. Po drugie, oba zostały napisane z pozycji świadomości jak fatalnie dla Bizantyńczyków zakończyła się wspomniana wyprawa zbrojna. I to widać w sposobie poprowadzenia narracji o niej, szczególnie u Wyznawcy, gdyż od samego jej początku konsekwentnie zmierza ona do tragicznego zakończenia, nie doceniając początkowego sukcesu. Cała wyprawa została przez naszych autorów oceniona z punktu widzenia jej zakończenia, a pełną odpowie-

56 F. Tinnefeld, Kategorien der Kaiserkritik in der byzantinischen Historiographie von Prokop bis Nicetas Choniates, München 1971, s. 74-79; P.E. Niavis, The Reign ..., s. 255-265; П. Ангелов, България и българите в представите на византийците (VII-XIV век), София 1999, s. 161-168; M.J. Leszka, Chan Krum i basileus Nikefor I w świetle Perí Nikefórou toú basiléos kaí pós afiesin tá kóla en Boulgaría, „Slavia Antiqua” 2002, nr 43, s. 38-42; idem, Wizerunek władców Pierwszego Państwa Butgarskiego w bizantyńskich źródłach pisanych (VIII-pierwsza połowa XII wieku), Łódź 2003, s. 44-47. 
dzialnością za klęskę obarczono cesarza, który miał inspirować (świadomie lub nie) bądź nie reagować na niegodne żołnierza czyny popełniane przez jego podwładnych. Powstaje zatem pytanie, na ile można ufać wskazanym przekazom, i jak oddzielić „ziarno od plewy”, które są w nich zawarte. Wydaje się niewątpliwe, że Nikefor mógł mieć przekonanie o odniesionym zwycięstwie nad Krumem, który dwa razy w toku kampanii zwracał się do niego z prośbą o zawarcie pokoju. W tej sytuacji, wycofując się z wolna $\mathrm{z}$ terytoriów bułgarskich, bez względu na to czy podążał do wspomnianej w Kronice Sardyki (twierdzy bizantyńskiej, zniszczonej dwa lata wcześniej przez Bułgarów) ${ }^{57}$, czy prosto na południe do Konstantynopola ${ }^{58}$ (w jednym i w drugim przypadku zmierzał na obszary bizantyńskie), zlekceważył możliwe zagrożenia ze strony przeciwnika, zaniedbując podstawowe środki ostrożności. Jest to szczególnie widoczne w kontekście ochrony obozu, który Bizantyńczycy rozbili na obszarze górskim, i którego nie strzegli w sposób należyty, zgodny z kanonami sztuki wojennej ${ }^{59}$. Paradoksalnie postawa Nikefora, wbrew intencjom naszych źródeł, świadczy o ogromie zwycięstwa odniesionego w pierwszej fazie kampanii. Zachłyśnięty nim cesarz, dwukrotnie odrzuciwszy porozumienie pokojowe, dowodzące w jego opinii słabości Kruma, uznał, że nie grozi mu już żadne niebezpieczeństwo ze strony tego ostatniego. No dobrze, ale co powyższe rozważania dają w kontekście działań wojska bizantyńskiego podejmowanych względem bułgarskiego zaplecza gospodarczego?

Uznając, że oba przekazy mówią o tych samych działaniach w rozpatrywanej przeze mnie materii, proponuję zracjonalizować ich przekaz, oczyszczając go z całej warstwy retorycznej, mającej na celu oczernienie bizantyńskiego władcy. Zgodnie z tym założeniem $\mathrm{w}$ danym przypadku mielibyśmy do czynienia $\mathrm{z}$ w pełni świadomym działaniem zarówno cesarza jak i podległej mu armii, działaniem jak najbardziej zasadnym $^{60}$. Otóż, wycofując się z obszaru Bułgarii Nikefor nakazał palić zbiory pozostające na polach i wybijać zwierzęta hodowlane, woły, owce i świnie (możliwe, że i inne, na przykład udomowione ptactwo). Innymi słowy polecił niszczyć zaplecze gospodarcze chanatu (szczególnie hinterland ośrodka stołecznego), w celu zadania jej władcy i jego poddanym jak największych strat materialnych. Niewykluczone, że temu miało służyć również zdziesiątkowanie ludności uprawiającej ziemię i zajmującej się hodowlą (czyli podatników), jak również żywą siłę bułgarskich sił zbrojnych, o ile nie mamy tu do czynienia wyłącznie z licentia poetica Teofanesa, co wydaje się

57 Theophanis chronographia, AM 6301, s. 485, 4-17.

58 С.Т. Недев, Разгромът, s. 125-126; P.E. Niavis, The Reign, s. 243-244; М.Й. Лешка, Цели, s. 60 , przyp. 18 .

59 К. Маринов, Стратегическата роля на Старопланинската и Средногорската вериги в светлината на българо-византийските военни сблъсъии през VII-XI век, „Известия на Регионален исторически музей - Габрово" 2014, nr 2, s. 113. Ogólnie na temat obozowania w obszarach górskich zob. idem, Бележки върху военния лагер на планинска територия според византийските стратегикони, „Bulgaria Mediaevalis” 2018, nr 9, s. 323-334.

60 P. Sophoulis, Byzantium and Bulgaria, s. 207-208, także optuje za świadomym działaniem cesarza (podobnie F. Curta, Eastern Europe, s. 89), wskazując jednak na inne cele, które mu przyświecały. 
wysoce prawdopodobne. Jednakże, jak już wskazywałem powyżej, wybicie miejscowej ludności wydaje się logiczną konsekwencją zniszczenia obszarów rolniczych (to samo dotyczy mieszkańców stolicy), ponieważ z całą pewnością były one zamieszkałe przez właścicieli uprawiających pola i hodujących zwierzęta. Oczywiście, nie można wykluczyć, że wiedząc o zbliżających się oddziałach bizantyńskich ludność ta porzuciła swoje dobra na łaskę losu, by ukryć się (na przykład w pobliskich lasach, wzniesieniach czy górach) i uratować swoje życie. Bizantyńczycy zastosowali zatem tzw. taktykę spalonej ziemi, działanie poświadczone i rekomendowane przez autorów wschodniorzymskich podręczników wojskowości ${ }^{61}$. Było to szczególnie zasadne, gdyż Pliska znajdowała się na obszarach północno-wschodniej Bułgarii, a więc terenach o najgęstszym w owym czasie zaludnieniu, gdy idzie o naddunajski chanat. Tutaj znajdowało się centrum państwa bułgarskiego, a rolnictwo i wypas zwierząt stanowiły jego gospodarcze podstawy ${ }^{62}$. Szczególnie to drugie zajęcie, z którego ziemie bułgarskie były znane przez cały okres średniowieczny ${ }^{63}$, a co podkreśla szczegółowość opisu anonimowego autora. Oczywiście, nie da się wykluczyć (a może należy to przyjąć za pewnik?), że podczas wykonywania tego zadania dochodzić mogło do aktów okrucieństwa wobec zwierząt, choć to również mógłby być odautorski dodatek, mający na celu jeszcze większą dyskredytację władcy, który na to pozwalał. Realizacja wspomnianej taktyki tłumaczy, dlaczego Nikefor nie opuścił obszarów bułgarskich pospiesznie. Podjęte działania wymagały czasu, nadto, jak już stwierdziłem, nie obawiał się żadnego zagrożenia ze strony wrogów. Dalekosiężny cel bizantyńskiego władcy obejmował wyłączenie Bułgarów z walk o tereny macedońskie i trackie, innymi słowy uniemożliwienie im przeszkadzania w bizantyńskiej rekonkwiście tych terytoriów ${ }^{64}$. Na możliwie najdłuższy czas. Cel, który udało się w jakimś stopniu Nikeforowi osiągnąć, nawet pomimo bułgarskiego zwycięstwa w górach Hemosu, gdyż Krum podjął ponowne działania zbrojne przeciwko Bizancjum dopiero prawie rok później ${ }^{65}$, co mogłoby świadczyć o tym, że odbudowanie znisz-

${ }^{61}$ Mauricii Strategicon, IX, 3, wyd. G.T. Dennis, thum. E. Gamillscheg, Vindobonae 1981, s. 314, 41-45; VIII, 1, (30), s. 274, 99-100; Leonis VI Tactica, IX, 22-23, wyd. G.T. Dennis, Washingtoniae 2010, s. 160, 97-162, 103; XVII, 34, s. 404, 181-185. Przed laty podzieliłem się tą ideą z Mirosławem J. Leszką, który, za moją zgodą, wykorzystał ją w swoim artykule (М.Й. Лешка, Цели, s. 60-61 oraz przyp. 20). W niniejszym tekście pragnę więc zaprezentować ją w pełniejszej wersji.

62 V. Beševliev, Die Protobulgarische Periode, s. 412-413; Р. Рашев, Прабългарите и Българското ханство на Дунав, София 2001, s. 125-126; Д. Димитров, П. Пьрванов, Стопанска история, Благоевград 2015, s. 69-75; K. Marinow, Gospodarka, w: M.J. Leszka, K. Marinow, Carstwo butgarskie. Polityka-Społeczeństwo-Gospodarka-Kultura, 866-971, Warszawa 2015, s. 289-291.

63 Por. Georgii Acropolitae Opera, 11, wyd. A. Heisenberg, t. 1, Lipsiae 1903, s. 18, 12-15; Мехмед Нешри, Огледало на света. История на османския двор, § 73, thum. М. Калицин, София 1984, s. 93.

64 Por. podobne twierdzenia już u П. Мутафчиев, История, s. 116, jakkolwiek wielki bułgarski uczony uważał, że działania cesarza wynikały z jego żądzy niszczenia i zemsty, a nie przemyślanej i uprzednio założonej strategii wojennej.

65 Theophanis chronographia, AM 6304, s. 495, 20-496, 2. 
czonej infrastruktury państwa (spalonej stolicy i gospodarki rolniczo-hodowlanej, a dlaczego nie i przesiedlenia na zniszczone terytoria nowych grup osadniczych, w celu odbudowania potencjału demograficznego) zajęło mu większość wskazanego przedziału chronologicznego.

Wszystko co powiedziano do tej pory zostało potwierdzone przez niezależne źródło z epoki, kamienną inskrypcję bułgarską ze wsi Hambarli (dziś Małamirowo), w której wprost wspomina się o późniejszych odwetowych działaniach militarnych chana Kruma i jego brata przeciwko terytoriom bizantyńskim w Tracji, skad wy-

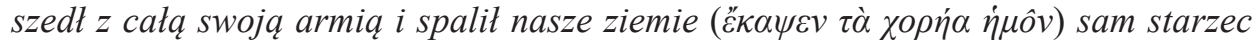

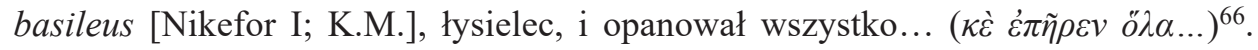
Określenie spalit może mieć charakter ogólny i zbiorczo oznaczać dewastację, rujnowanie, niszczenie obszarów bułgarskich, a więc każdy rodzaj antybułgarskich akcji, nawet eksterminację miejscowej ludności, lecz dodatkowa wzmianka o opanowaniu wszystkiego wskazuje raczej na konkretne działania, co jednoznacznie potwierdza świadectwo Anonima (i Teofanesa) o spaleniu siedziby chana i niezżętych pól uprawnych. Tekst wyraźnie podkreśla działania, którym poświęcił się władca bizantyński w czasie pobytu w państwie bułgarskim. Z kolei wzmianka o tym, że basileus opanował „wszystko” dowodzi rozmiarów przedsięwzięcia, zarówno w wymiarze materialnym, jak i przestrzennym, jakkolwiek zleceniodawca inskrypcji miał najprawdopodobniej na myśli przede wszystkim stołeczną Pliskę i główną siedzibę chana.

Działania wycofującej się z terytoriów bułgarskich armii bizantyńskiej dowodzą jeszcze czegoś innego, a mianowicie tego, że celem inwazji Nikefora nie było realne podbicie Bułgarii i włączenie jej w obręb granic cesarstwa, jak sądzi wielu współczesnych uczonych zajmujących się tą tematyką ${ }^{67}$. Dowodzi tego nie tylko samo złupienie i zniszczenie stolicy bułgarskiej, czy też niszczenie okolicznych zasobów gospodarczych, lecz również brak pozostawienia własnych oddziałów zbrojnych na terytoriach bułgarskich. Chodziło zatem jedynie o paraliż wewnątrz Bułgarii, o wy-

66 В. Бешевлиев, Първобългарски надписи (Второ преработено и допълнено издание), София 1992, s. 117, 27-32.

67 Zob. S. Runciman, The History of the First Bulgarian Empire, London 1930, s. 55; Ив. Дуйчев, Нови житийни данни, s. 160; G. Ostrogorski, Dzieje Bizancjum, przekład pod redakcją H. EvertKapessowej, Warszawa 1968, s. 177; T. Wasilewski, Bizancjum i Stowianie w IX w. Studia z dziejów politycznych i kulturalnych. Warszawa 1972, s. 50; В. Бешевлиев, Крум, s. 20; J.V.A. Fine, The Early Medieval Balkans. A Critical Survey from the Sixth Century to the Late Twelfth Century, Ann Arbor 1983, s. 96; П. Ангелов, Българската средновековна дипломаџия, София 1988, s. 90 (uwaga o charakterze ogólnym); P.E. Niavis, The Reign..., s. 235; W. Treadgold, The Byzantine Revival..., s. 168; M. Whittow, The Making of Orthodox Byzantium, 600-1025, Berkeley-Los Angeles 1996, s. 280; В. Гюзелев, Езическа България, s. 128; J. Haldon, The Byzantine Wars..., s. 71; Й. Андреев, Крум, s. 407, 408. Por. bardziej stonowanie opinie u J.B. Bury, A History of the Eastern Roman Empire from the Fall of Irene to the Accession of Basil I. (A.D. 802-867), New York 1965 (pierwsze wydanie w 1912 r.), s. 343-344; В.Н. Златарски, История..., s. 256-257; П. Мутафчиев, История, s. 116. 
łączenie jej ze zmagań o wspomniane wcześniej tereny ${ }^{68}$. W pewnym sensie wskazuje na to również dosłowne rozumienie słownictwa wykorzystanego w tekście anonimowej kroniki, charakteryzującego cele bizantyńskiego władcy wobec północnej sąsiadki imperium. Wyruszył on bowiem na wyprawę przeciwko Bułgarii, chcąc ją zniszczyć ( $\dot{\alpha} \varphi \alpha v i \sigma \alpha l)$, a po opuszczeniu stolicy Kruma był przekonany, że zniszczył ( $\dot{\varepsilon} \xi \dot{\eta} \lambda \varepsilon l \psi \varepsilon v)$ cały kraj ${ }^{69}$. A zatem jakby nie chodziło o podbicie i inkorporację do własnego władztwa, lecz o zrujnowanie, zniszczenie i likwidację, co by odpowiadało informacjom występującym w inskrypcji bułgarskiej. Jakie dalsze plany miał bizantyński władca nigdy się nie dowiemy, gdyż zginął na polu ostatniej bitwy tej kampanii.

\section{BIBLIOGRAFIA}

\section{Źródła:}

Aias, w: Sophoclis Tragoediae, t. 1, Aiax, Electra, Oedipus rex, wyd. Roger David Dawe, Leipzig 1984, s. 1-49. [Aïas, w: Sophoclis Tragoediae, t. 1, Aiax, Electra, Oedipus rex, wyd. Roger David Dawe, Leipzig 1984, s. 1-49].

Anastasii Bibliothecarii summae ac Apostolicae Sedis Chronographia Tripertita, w: Theophanis chronographia. wyd. Carl de Boor, t. 2, Theophanis vitas, Anastasii Bibliothecarii Historiam Tripertitam, Disserationem de codicibus operis Theophanei indices, Lipsiae 1885, s. 31-346.

Annales Einhardi, wyd. Georg Heinrich Pertz, w: Monumenta Historiae Germanica. Scriptorum, t. 1, Hannoverae 1826, s. 135-218.

Anonymi auctoris Chronikon ad. A.C. 1234 pertinens II, thum. Albert Abouna, oprac. Jean-Maurice Fiye, Louvain 1974.

Beševliev Veselin, Părvobălgarski nadpisi (Vtoro preraboteno i dopălneno izdanie), Sofija] 1992 [Бешевлиев Веселин, Първобългарски надписи (Второ преработено и допълнено издание), София 1992].

Chronique de Michel le Syrien, patriarche jacobite d'Antioche (1166-1199), wyd. Jean-Baptiste Chabot, t. 3, Paris 1905.

Clugnet, Léon, Histoire de saint Nicolas, soldat et moine, "Revue de l'Orient Chrétien" 1902, nr 7, s. 319-330.

Epi te ton Boulgaron symbasei, w: Ivan Dujčev, On the Treaty of 927 with the Bulgarians, "Dumbarton

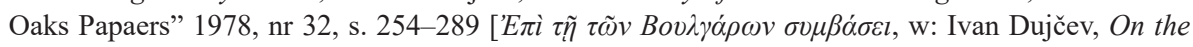
Treaty of 927 with the Bulgarians, "Dumbarton Oaks Papaers" 1978, nr 32, s. 254-289].

Georgii Acropolitae Opera, wyd. August Heisenberg, t. 1, Lipsiae 1903.

68 Również i inni uczeni wyrażają wątpliwości na temat celów Nikefora I: R. Browning, Byzantium and Bulgaria. A comparative study across the early medieval frontier, London 1975, s. 49; J. Shepard, Slavs and Bulgars, w: The New Cambridge Medieval History, t. 2, c. 700-c. 900, wyd. R. McKitterick, Cambridge 1995, s. 234-235; J. Haldon, Warfare, State and Society in the Byzantine World, 565-1204, London 1999, s. 40; Б. Примов, Укрепване и териториално разширение на българската държава през първата половина на IX в., w: История на България в четиринадесет тома, t. 2, Първа българска държава, red. Д. Ангелов, София 1981, s. 133-134; М.Й. Лешка, Цели, s. 57-60, 62; Ив. Божилов, История на Средновековна България, t. 1, Варварска България, Пловдив 2017, s. 287-288.

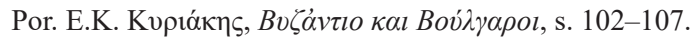

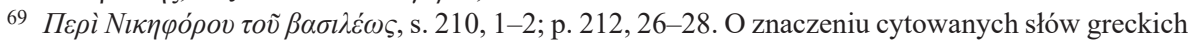
zob. A Greek-English Lexicon, s. 286, 583; I. Dujčev, La chronique byzantine, s. 233. 
Georgius Cedrenus-Ioannis Scylitzae Opera, wyd. Immanuel Bekker, t. 2, Bonnae 1839.

Gesta episcoporum Neapolitanorum, wyd. Georg Waitz, w: Monumenta Historiae Germanica. Scriptores rerum Langobardicarum et Italicarum saec. VI-IX, Hannoverae 1878, s. 398-439.

Mauricii Strategicon, wyd. George T. Dennis, thum. Ernst Gamillscheg, Vindobonae 1981.

Mehmed Nešri, Ogledalo na sveta. Istorija na osmanskija dvor przekł. Marija Kalicin, Sofija 1984

[Мехмед Нешри, Олледало на света. История на османския двор, przekł. Мария Калицин, София 1984].

Nicolae I. papae epistolae, wyd. Ernst Perels, w: Monumenta Germaniae Historica. Epistolae, t. 6, Karolini aevi IV, Berolini 1925, s. 257-690.

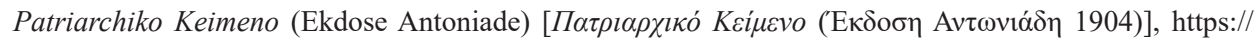
www.bible.com/bible/209/MAT.2.BYZ04 [dostęp: 22.08.2020].

Peri Nikeforou tou basileos kai pos afiesin ta kola en Boulgaria, w: Ivan Dujčev, La chronique byzan-

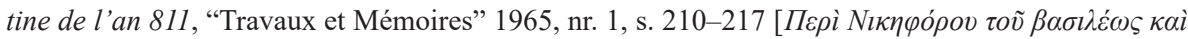

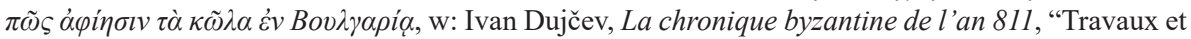
Mémoires" 1965, nr. 1, s. 210-217].

Reginonis Chronicon, wyd. Georg Heinrich Pertz, w: Monumenta Historiae Germanica. Scriptorum, t. 1, Hannoverae 1826, s. 537-629.

Septuaginta. Id est Vetus Testamentum grecae iuxta LXX interpretes, wyd. Alfred Rahlfs, przel. Robert Hanhart, t. 2, Libri poetici et prophetici, Stuttgart 2006.

Sigeberti Gemblacensis Chronographia, wyd. Ludwig Conrad Bethmann, w: Monumenta Historiae Germanica. Scriptorum, t. 6, wyd. Georg Heinrich Pertz, Hannoverae 1844, s. 268-374.

Testimonia najdawniejszych dziejów Słowian. Seria grecka, red. Alina Brzóstkowska, Wincenty Swoboda, z. 3 (Pisarze z VII-X wieku), Wrocław 1995.

The Chronicle of Theophanes Confessor. An English translation of anni mundi 6095-6305 (A.D. 602813), tłum. Harry Turtledove, Philadelphia 1982.

The Chronicle of Theophanes Confessor. Byzantine and near East History AD 284-813, thum. Cyril Mango i Roger Scott, wsparcie Geoffrey Greatrex, Oxford 1997.

The Chronography of Gregory Abu'l-Faraj, the Son of Aaron, the Hebrew Physician, commonly known as Bar Hebraeus (1225-1286), thum. Ernest Alfred Wallis Budge, t. 1, English Translation, Amsterdam 1976 (reprint z 1932 r.).

Theophanis chronographia, wyd. Carl de Boor, t. 1, Lipsiae 1883.

Theophanis Confessoris Chronographia, tłum. V. Beševliev, G. Cankova-Petkova, wstęp i kom. idem, w: Fontes graeci historiae bulgaricae, t. 3, wyd. I. Dujčev, G. Cankova-Petkova, V. TăpkovaZaimova, L. Jončev, P. Tivčev, Sofia, [s. a.], s. 226-289.

Theophanis Continuati, wyd. Immanuel Bekker, Bonnae 1838.

Vita de S. Petro Patricio Conf., w: Acta Sanctorum, Julii, t. 1, wyd. Conrado Ianningo, Joanne Sollerio, Joanne Pinio, red. Joanne Carnandet, Parisiis et Romae 1867, ps 257-258.

\section{Opracowania i artykuły:}

A Greek-English Lexicon, red. Henry George Liddell, Robert Scott, Oxford 1996.

Andreev Jordan, Krum, w: Jordan Andreev, Ivan Lazarov, Plamen Pavlov, Koj koj e v Srednovekovna Bălgarija (Treto dopălneno i osnovno preraboteno izdanie), Sofija 2012, s. 406-413 [Андреев Йордан, Крум, w: Йордан Андреев, Иван Лазаров, Пламен Павлов, Кой кой е в Средновековна България (Трето допълнено и основно преработено издание), София, 2012, s. 406-413].

Angelov Dimităr, Kašev Stefan, Čolpanov Boris, Bălgarska voenna istorija ot Antičnostta do vtorata četvărt na X v., Sofija 1983 [Ангелов Димитър, Кашев Стефан, Чолпанов Борис, Българска военна история от Античността до втората четвърт на Х в., София 1983].

Angelov Petăr, Bălgarija i bălgarite v predstavite na vizantijcite, Sofija 1999 [Ангелов Петър, България и българите в представите на византийците (VII-XIV век), София 1999].

Angelov Petăr, Bălgarskata srednovekovna diplomacija, Sofija 1988 [Ангелов Петър, Българската средновековна дипломация. София 1988]. 
Atanasov Šterjo, Dujčev Ivan, Angelov Dimităr, Cankova-Petkova Genoveva, Christov Dimităr, Čolpanov Boris, Bălgarskoto voenno izkustvo prez feodalizma, Sofija 1958 [Атанасов Щерьо, Дуйчев Иван, Ангелов Димитър, Цанкова-Петкова Геновева, Христов Димитьр, Чолпанов Борис, Българското военно изкуство през феодализма, София 1958].

Beševliev Veselin, Die Protobulgarische Periode der bulgarischen Geschichte, Amsterdam 1981.

Beševliev Veselin, Krum i Nikifor, „Studia Balcanica” 1983, nr 17, s. 17-26 [Бешевлиев Веселин, Крум и Никифор, „Studia Balcanica” 1983, nr 17, s. 17-26].

Beševliev Veselin, Novijat izvor za poraženieto na Nikifora I v Bălgarija prez 811 godina, „Godišnik na Sofijskija Universitet. Istoriko-filologičeski fakultet” 1936, nr 33.2, s. 1-8 [Бешевлиев Веселин, Новият извор за поражението на Никифора I в България през 811 година, „Годишник на Софийския Университет. Историко-филологически факултет” 1936, nr 33.2, s. 1-8].

Božilov Ivan, Istorija na Srednovekovna Bălgarija, t. 1 (Varvarska Bălgarija), Plovdiv 2017 [Божилов Иван, История на Средновековна България, t. 1 (Варварска България), Пловдив 2017].

Browning Robert, Byzantium and Bulgaria. A comparative study across the early medieval frontier, London 1975.

Browning Robert, Notes on the «Scriptor Incertus de Leone Armenio», „Byzantion” 1965, nr 35, s. 389-411.

Brubaker Leslie, Haldon John F., Byzantium in the Iconoclast Era, c. 660-850: A History, Cambridge 2011.

Bury John Bagnell, A History of the Eastern Roman Empire from the Fall of Irene to the Accession of Basil I. (A.D. 802-867), New York 1965.

Chabot Jean-Baptiste, Introduction, w: Chronique de Michel le Syrien, patriarche jacobite d'Antioche (1166-1199), wyd. Jean-Baptiste Chabot, t. 1, Paris 1899, s. I-LX.

Chrisimov Nikolaj, „, Otgovorite na papa Nikolaj I do dopitvanijata na bălgarite“ kato izvor za bita i ežednevieto na bălgarite po vremeto na knjaz Boris I, w: Bălgarija, bălgarite i Evropa - mit, istorija, săvremie, t. 4, Dokladi ot Meždunarodna konferencija v pamet na prof. din Jordan Andreev „Bălgarija, zemja na blaženi... “, Veliko Tărnovo, 29-31 oktomvri 2009 g., Veliko Tărnovo, 2011, s. 149-172 [Хрисимов Николай, „Отговорите на папа Николай I до допитванията на българите“ като извор за бита и ежедневието на българите по времето на княз Борис I, w: България, българите и Европа-мит, история, съвремие, t. 4, Доклади от Международна конферениия в памет на проф. дин Йордан Андреев „България, земя на блажени... “, Велико Търново, 29-31 октомври 2009 г., Велико Търново 2011, s. 149-172].

Christov Dimităr, Vojnata meždu Bălgarija i Vizantija prez 811 g., „Izvestija na Voennoistoričeskoto družestvo" 1967, nr 4, s. 64-95 [Христов Димитър, Войната между България и Византия през 811 г., „Известия на Военноисторическото дружество” 1967, nr 4, s. 64-95].

Constantelos Demetrios J., Byzantine Philanthropy and Social Welfare, New Brunswick-New Jersey 1968.

Curta Florin, Eastern Europe in the Middle Ages (500-1300), Leiden-Boston 2019.

Dermendžiev Evgeni, Edna chipoteza za pochoda na imperator Nikifor I Genik v Bălgarija, w: Studia protobulgarica et mediaevalia europensia. V čest na profesor Veselin Beševliev, red. Kazimir Popkonstantinov, Sofija 2003, s. 401-408 [Дерменджиев Евгени, Една хипотеза за похода на император Никифор I Геник в България, w: Studia protobulgarica et mediaevalia europensia. В чест на професор Веселин Бешевлиев, red. Казимир Попконстантинов, София 2003, s. 401408].

Dimitrov Dimităr, Părvanov Petăr, Stopanska istorija, Blagoevgrad 2015 [Димитров Димитър, Първанов Петьр, Стопанска история, Благоевград 2015].

Dujčev Ivan, La chronique byzantine de l'an 811, „Travaux et Mémoires” 1965, nr 1, s. 205-254.

Dujčev Ivan, Novi žitijni danni za pochoda na Nikifora I v Bălgarija prez 811 god., „Spisanie na Bălgarskata akademija na naukite, 54, Klon istoriko-filologičen i Filosofsko-obštestven” 1937, nr 26, s. 147-188 [Дуйчев Иван, Нови житийни данни за похода на имп. Никифора I в България през 811 год., „Списание на Българската академия на науките, 54, Клон историко-филологичен и Философско-обществен” 1937, nr 26, s. 147-188]. 
Dujčev Ivan, Rösener Werner, Balkan, w: Lexikon des Mittelalters, Bd. I, München-Zürich 1977, s. 1380 1381.

Fine John Van Antwerp, The Early Medieval Balkans. A Critical Survey from the Sixth Century to the Late Twelfth Century, Ann Arbor 1983.

Gagova Krasimira, Trakija prez bălgarskoto Srednovekovie. Istoričeska geografija, Sofija 2002 [Гагова Красимира, Тракия през българското Средновековие. Историческа география, София 2002].

Gjuzelev Vasil, Ezičeska Bălgarija, in: Ivan Božilov, Vasil Gjuzelev, Istorija na srednovekovna Bălgarija VII-XIV vek, Sofija 1999, s. 55-166 [Гюзелев Васил, Езическа България, w: Иван Божилов, Васил Гюзелев, История на средновековна България VII-XIV век, София 1999, s. 55-166].

Golijski Petăr, Drevnite i srednovekovnite bălgari v sirijskite i sirijsko-armenskite izvori, „Epohi” 2019, nr. 27.2, s. 415-472 [Голийски Петър, Древните и средновековните българи в сирийските и сирийско-арменските извори, „Епохи” 2019, nr. 27.2, s. 415-472].

Grégoire Henri, Du nouveau sur la Chronographie byzantine: «Scriptor incertus de Leone Armenio» est le dernier continuateur de Malalas, „Bulletin de la Classe des Lettres de L'Academie de Belgique” 1936, nr 5, s. 420-436.

Grégoire Henri, Un nouveau fragment du «Scriptor Incertus de Leone Armenio», „Byzantion” 1936, nr 11, s. 417-427.

Haldon John, The Byzantine Wars. Battles and campaigns of the Byzantine era, Stroud 2001.

Haldon John. Warfare, State and Society in the Byzantine World, 565-1204, London 1999.

Hilkens Andy, The Anonymous Syriac Chronicle up to the Year 1234 and its Sources, Proefschrift voorgelegd tot het behalen van de graad van Doctor in de geschiedenis. Universiteit Gent, Faculteit Letteren \& Wijsbegeerte, 2014, https://biblio.ugent.be/publication/4381496/file/4381498.pdf [dostęp: 2324.08.2020].

Hoyland Robert G., Seeing Islam as Others saw It: A Survey and Evaluation of Christian, Jewish and Zoroastrian Writings on Early Islam, Princeton 1997.

Inalcık Halil, Balkan, w: The Encyclopaedia of Islam. New Edition, t. 1, $A-B$, wyd. Hamilton Alexander Rosskeen Gibb, Johannes Hendrik Kramers, Évariste Lévi-Provençal, Bernard Lewis, Charles Pellat, Joseph Schacht, Leiden-London 1960, s. 998-1000.

Karayiannopoulos Ioannes, Kroumos kai Filippoi. Oi Bydzantinoboulgarikes epicheireseis, w: Byzantium. Tribute to Andreas N. Stratos, wyd. Andreas N. Stratos, t. 1 (History, Art and Architecture), Athens

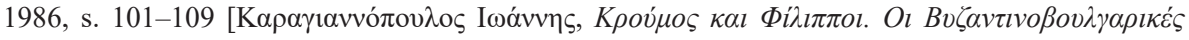

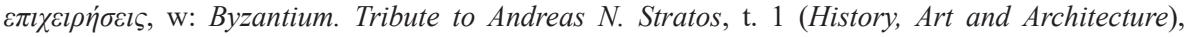
wyd. Andreas N. Stratos, Athens 1986, s. 101-109].

Kazhdan Alexander Petrovich, Balkans, w: The Oxford Dictionary of Byzantium, wyd. Alexander Petrovich Kazhdan, t. 1, New York-Oxford 1991, s. 248-249.

Kazhdan Alexander, Lee Francis Sherry, Christina Angelidi, A History of Byzantine Literature (650-850), Athens 1999.

Kazhdan Alexander, Lee Sherry, Some Notes on the "Scriptor Incertus de Leone Armenio», „Byzantinoslavica” 1997, nr 58, s. 110-112.

Kominis Athanasios, Echi della battaglia dell'anno 811 tra Bizantini e Bulgari in testi agiografici, w: Actes du premier Congres International des Études Balkaniques et Sud-Est Européennes, Sofia, 26 âout - 1 septembre 1966, t. 3, Histoire (Ve-XVe ss.; XVe-XVIIe ss.), wyd. Vasilka TăpkovaZaimova, Strašimir Dimitrov, Elena Sarafova, Sofia 1969, s. 313-318.

Kompa Andrzej, Gnesioi filoi: the Search for George Syncellus' and Theophanes the Confessor's Own Words, and the Authorship of Their Oeuvre, „Studia Ceranea” 2015, nr 5, s. 155-230.

Korres Theodoros, E bydzantinoboulgarike antiparathese stis arches tou 9ou ai. kai e sfage ton strateumaton tou Nikeforou A ste Boulgaria (Ioulios 811), „Bydzantina” 1995/1996, nr 18, s. 167

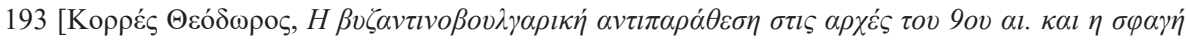

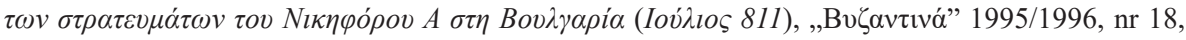
s. 167-193]. 
Krăstev Krasimir S., Arabski i sirijski izvori za upravlenieto na chanovete Krum (sled 796-814) i Omurtag (814-okolo 831), w: Bălgarsko carstvo. Sbornik v čest na 60-godnišninata na doc. d-r Georgi N. Nikolov, red. Angel Nikolov, Sofija, 2018, s. 276-303 [Кръстев Красимир С., Арабски и сирийски извори за управлението на хановете Крум (след 796-814) и Омуртаг (814-около 831), w: Българско иарство. Сборник в чест на 60-годиинината на дои. д-р Георги Н. Николов, red. Ангел Николов, София, 2018, s. 276-303].

Kyriakes Euangelos K., Bydzantio kai Boulgaroi (7os-10os ai.). Symbole sten eksoterike politike tou

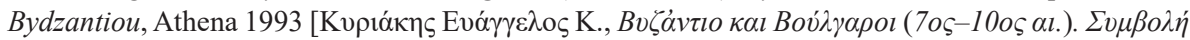

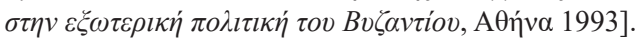

Lehr-Spławiński Tadeusz, Bałkany, w: Stownik Starożytności Stowiańskich. Encyklopedyczny zarys kultury Słowian od czasów najdawniejszych do schyłku wieku XII, t. 1, A-E, wyd. Władysław Kowalenko, Gerard Labuda, Tadeusz Lehr-Spławiński, Wrocław-Warszawa-Kraków 1961, s. 71.

Lesky Albin, Die tragische Dichtung der Hellenen, Göttingen 1972.

Leszka Mirosław Jerzy, Celi pochoda Nikifora I protiv bolgar v 811 godu, w: Byzantium, New Peoples, New Powers: The Byzantino-Slav Contact Zone, from the Ninth to the Fifteenth Century, red. Miliana Kaimakamova, Maciej Salamon, Małgorzata Smorąg Różycka, Cracow, 2007, s. 55-62 [Лешка Мирослав Йежи, Цели похода Никифора I против болгар в 811 году, w: Byzantium, New Peoples, New Powers: The Byzantino-Slav Contact Zone, from the Ninth to the Fifteenth Century, red. Miliana Kaimakamova, Maciej Salamon, Małgorzata Smorąg Różycka, Cracow, 2007, s. 55-62].

Leszka Mirosław Jerzy, Chan Krum i basileus Nikefor I w świetle Perí Nikefórou toú basiléos kai pós afiesin tá kóla en Boulgaría, „Slavia Antiqua” 2002, nr 43, s. 35-43.

Leszka Mirosław Jerzy, Leon V $i$ chan Krum w świetle fragmentu Chronografii (AM 6305) Teofanesa Wyznawcy, „Przegląd Nauk Historycznych” 2007, nr 6.1-2, s. 109-117.

Leszka Mirosław Jerzy, Wizerunek władców Pierwszego Państwa Bułgarskiego w bizantyńskich źródłach pisanych (VIII-pierwsza połowa XII wieku), Łódź 2003.

Marinow Kirił, Beležki vărchu voennija lager na planinska teritorija spored vizantijskite strategikoni, „Bulgaria Mediaevalis” 2018, nr 9, s. 323-334 [Маринов Кирил, Бележки върху военния лагер на планинска територия според византийските стратегикони, „Bulgaria Mediaevalis” 2018, nr 9, s. 323-334].

Marinow Kirił, Gospodarka, w: Mirosław Jerzy Leszka, Kirił Marinow, Carstwo bułgarskie. PolitykaSpołeczeństwo-Gospodarka-Kultura, 866-971, Warszawa 2015, s. 277-304.

Marinow Kirił, Strategičeskata rolja na Staroplaninskata i Srednogorskata verigi v svetlinata na bălgaro-vizantijskite voenni sblăsăci prez VII-XI vek, ,Izvastija na Regionalen istoričeski muzej Gabrovo" 2014, nr 2, s. 111-134 [Маринов Кирил, Стратегическата роля на Старопланинската и Средногорската вериги в светлината на българо-византийските военни сблъсъци през VII-XI век, „Известия на Регионален исторически музей Габрово” 2014, $\mathrm{nr} 2$, s. 111-134].

Marinow Kirił, The Haemus Mountains and the Geopolitics of the First Bulgarian Empire: An Overview, „Zbornik radova Vizantološkog instituta” / „Зборник радова Византолошког института” 2014, nr 51, s. 17-32.

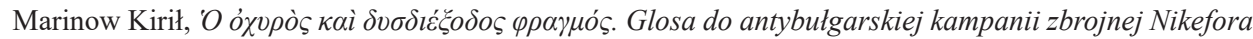
I z 811 r., „Stupskie Studia Historyczne” 2011, nr 17, s. 9-18.

Markopoulos Athanassios, La Chronique de l'an 811 et le Scriptor Incertus de Leone Armenio: problèmes des relations entre l'hagiographie et l'histoire, „Revue des Études Byzantines” 1999, nr 57, s. $255-262$.

Marquart Josef, Osteuropäische und ostasiatische Streifzüge Ethnologische und historisch-topographische Studien zur Geschichte des 9. und 10. Jahrhunderts (ca. 840-940), Leipzig 1903.

Michajlov Stojan, Lungarova Pepa, Chronikata na Zigebert $i$ svedenijata mu za bălgarite v perioda 680-820 g., „Epohi” 2017, nr 25.2, s. 448-471 [Михайлов Стоян, Лунгарова Пепа, Хрониката на Зигеберт и сведенията му за българите в периода 680-820 г., „Епохи” 2017, nr 25.2, s. 448-471]. 
Momčilov Dimčo, Kăde Nikifor I Genik preminava Iztočna Stara planina prez 811 g. po napravlenieto Markeli-Pliska, „Upravlenie i obrazovanie” 2013, nr 9.4, s. 142-151 [Момчилов Димчо, Къде Никифор I Геник преминава Източна Стара планина през 811 г. по направлението МаркелиПлиска, „Управление и образование” 2013, nr 9.4, s. 142-151].

Momčilov Dimčo, Markeli v pochoda na vizantijskija imperator Nikifor I Genik prez 811 g. i otvetnija udar na Krum, „Godišnik na Universitet 'Prof. d-r Asen Zlatarov”” 2011, nr 40, s. 224-230 [Момчилов Димчо, Маркели в похода на византийския император Никифор I Геник през 811 г. и ответния удар на Крум, „Годишник на Университет “Проф. д-р Асен Златаров”” 2011, nr 40, s. 224-230].

Momčilov Dimčo, Ošte vednăž za pochoda na Nikifor I Genik prez 811 g., w: Bălgarsko srednovekovie: obštestvo, vlast, istorija. Sbornik v čest na prof. d-r Milijana Kajmakamova, red. Georgi N. Nikolov, Sofija, 2013, s. 221-228 [Момчилов Димчо, Още веднъж за похода на Никифор I Геник през 811 г., w: Българско средновековие: общество, власт, история. Сборник в чест на проф. д-р Милияна Каймакамова, red. Георги Н. Николов, София, 2013, s. 221-228].

Moszyński Leszek, Swoboda Wincenty, Haemus, w: Stownik Starożytności Stowiańskich. Encyklopedyczny zarys kultury Stowian od czasów najdawniejszych do schyłku wieku XII, t. 2, $F-K$, red. Władysław Kowalenko, Gerard Labuda, Tadeusz Lehr-Spławiński, Wrocław-WarszawaKraków 1964, s. 182.

Mutafčiev Petăr, Istorija na bălgarskija narod, t. 1, Părvo bălgarsko carstvo, Sofija 1992 [Мутафчиев Петър, История на българския народ, t. 1, Първо българско иарство, София 1992].

Nedev Stefan T., Razgromăt na Nikifor I Genik prez 811 g., „Voennoistoričeski sbornik” 1977, nr 46.1, s. 115-127 [Недев Стефан Т., Разгромът на Никифор I Геник през 811 г., „Военноисторически сборник" 1977, nr 46.1, s. 115-127].

Niavis Pavlos E., The Reign of the Byzantine Emperor Nicephorus I (AD 802-811), Athens 1987.

Nikolov Vasil, Jordanova Marina, Planinite v Bălgarija, Sofija, 2002 [Николов Васил, Йорданова Марина, Планините в България, София, 2002].

Oberhummer Eugen, Haimos, w: Paulys Real-Encyclopädie der classischen Altertumswissenschaft, t. 7/2, red. Wilhelm Kroll, Stuttgart 1912, s. 2221-2226.

Ostrogorski Georg, Dzieje Bizancjum, przekład pod redakcją Haliny Evert-Kapessowej, Warszawa 1968.

Pavlov Plamen, Zabravenoto Srednovekovie, Sofija, 2019 [Павлов Пламен, Забравеното Средновековие, София, 2019].

Primov Boris, Ukrepvane i teritorialno razširenie na bălgarskata dăržava prez părvata polovina na IX v., w: Istorija na Bălgarija v četirinadeset toma, t. 2, Părvo bălgarska dăržava, red. Dimităr Angelov, Sofija 1981, s. 130-161 [Примов Борис, Укрепване и териториално разширение на българската държава през първата половина на IX в., w: История на България в четиринадесет тома, t. 2, Първа българска държава, red. Димитър Ангелов, София 1981, s. 130-161].

Rašev Rašo, Prabălgarite i bălgarskoto chanstvo na Dunav, Sofija, 2001 [Рашев Рашо, Прабългарите и Българското ханство на Дунав, София, 2001].

Runciman Steven, The History of the First Bulgarian Empire, London 1930.

Shepard Jonathan, Slavs and Bulgars, w: The New Cambridge Medieval History, t. 2, c. 700-c. 900, red. Rosamond McKitterick, Cambridge 1995, s. 228-248.

Stownik łacińsko-polski, red. Marian Plezia, t. 3, Warszawa 2007.

Sophoulis Panos, Byzantium and Bulgaria, 775-831, Leiden-Boston 2012.

Sophoulis Panos, The Chronicle of 811, the Scriptor incertus and the Byzantine-Bulgar wars of the early ninth century, „Bulgaria Mediaevalis” 2010, nr 1, s. 381-388.

Soustal Peter, Thrakien (Thrakē, Rodopē und Haimimontos), Tabula Imperii Byzantini, Bd. VI, Wien 1991.

Stanev Kamen, Dărvenata pregrada v staroplaninskija prochod prez 811 g., „Istorija” 2007, nr 15.5/6, s. 1-4 [Станев Камен, Дървената преграда в старопланинския проход през 811 г., „История” 2007, nr 15.5/6, s. 1-4]. 
Stephenson Paul, "About the Emperor Nikephoros and How he Leaves his Bones in Bulgaria": A Context for the Controversial Chronicle of 811, „Dumbarton Oaks Papers” 2006, nr 60, s. 87-109.

Tinnefeld Franz, Kategorien der Kaiserkritik in der byzantinischen Historiographie von Prokop bis Nicetas Choniates, München 1971.

Travaux et Mémoires, nr 19, Studies in Theophanes, red. Marek Jankowiak, Federico Montinaro, Paris 2015.

Treadgold Warren, The Byzantine Revival 780-842, Stanford 1988.

Treadgold Warren, The Middle Byzantine Historians, New York-Basingstoke 2013.

Turlej Stanisław, The collapse of the Avar Khaganate and the situation in the southern Balkans. Byzantine and Bulgarian relations in the early 9th century. The birth of Krum's power and its foundations, w: Byzantina et Slavica Cracoviensia, t. 5, Byzantium, New Peoples, New Powers: the ByzantinoSlav Contact Zone, from the Ninth to the Fifteenth Century, red. Miliana Kaimakamova, Maciej Salamon, Małgorzata Smorąg Różycka, Cracow 2007, s. 31-54.

Wasilewski Tadeusz, Bizancjum i Stowianie w IX w. Studia z dziejów politycznych i kulturalnych, Warszawa 1972.

Whittow Mark, The Making of Orthodox Byzantium, 600-1025, Berkeley-Los Angeles 1996.

Wolfram Herwig, History of the Goths, transl. Thomas J. Dunlap, Berkeley-Los Angeles-London 1990. Wortley John, Legends of Byzantine Disaster of 811, „Byzantion” 1980, nr 50, s. 533-562.

Zlatarski Vasil Nikolov, Istorija na bălgarskata dăržava prez srednite vekove, t. 1, część 1, Epocha na chuno-bălgarskoto nadmoštie (679-852), Sofija 1918 [Златарски Васил Николов, История на българската държава през средните векове, t. 1, сzęść 1, Епоха на хуно-българското надмощие (679-852), София 1918]. 